\title{
Cartographies of Race and Class: Mapping the Class-Monopoly Rents of American Subprime Mortgage Capital
}

Elvin Wyly, ewyly@geog.ubc.ca

Markus Moos, mmoos@interchange.ubc.ca

Emanuel Kabahizi, manu94@yahoo.com

The University of British Columbia

February, 2008

\begin{abstract}
Hundred-billion dollar writedowns and trillion-dollar stock market fluctuations have drawn worldwide attention to America's subprime mortgage sector, and its linkages with predatory exploitation in working-class and racially marginalized communities. During nearly two decades of stealth expansion, agents of subprime capital fought regulation and reform by a) using the doctrine of risk-based pricing to equate financial innovation with democratized access to capital, b) appealing to the cultural myths of the 'American Dream' of homeownership, and c) dismissing well-documented cases of racial discrimination and predatory abuse as anecdotal evidence of rare problems confined to a few lost-cause places in what is otherwise a benevolent free-market landscape. The current crisis has undermined the third claim, but mainstream policy debates are reinforcing the first two. In this paper, we challenge all three of these ideological claims. Properly adapted and updated, Harvey's (1974) theory of class-monopoly rent explains how the localized, neighborhood exploitations of class and race in urban America have been woven through Wall Street into transnational webs of structured finance and investment. We map the race and class segmentation of subprime mortgage capital across several hundred U.S. metropolitan areas in 2004 and 2006, and we also analyzed the achievements and prospects of several progressive challenges to subprime exploitation.
\end{abstract}

\section{Subprime Goes Prime Time}

America's long-running boom in subprime mortgages met its catastrophic end in 2007. For years, an interdisciplinary group of scholars, attorneys, and activists diagnosed the gathering dangers in the sector, which is designed to provide high-cost, high-risk credit to low-income consumers and others with poor credit histories (Carr and Kolluri 2001; Engel and McCoy 2002; Mansfield 2000; Renuart 2004; Squires 1992, 2003, 2004). It is universally recognized, by analysts across the political spectrum, that subprime lending is disproportionately concentrated among racial and ethnic minority individuals and neighborhoods. For more than a decade, progressives have documented the proliferation of ever more aggressive tactics of deception, fraud, and legal-yet-abusive practices in the subprime market, and advocates sought regulatory reforms to combat the syndrome of racially discriminatory and "predatory" lending (Engel and McCoy 2002; HUD-Treasury Joint Task Force 2000). Yet conservatives have applauded subprime lending as a case of benevolent, risk-based pricing, and have subverted nearly all reform efforts by appealing to the American ideology of consumer sovereignty: if a consumer wishes to borrow money, and a bank is willing to lend, how could that possibly be bad or predatory? Progressives' answers to this simple question were detailed, rigorous, precise, and 
thus easily ignored amidst a national credit binge fueled by falling interest rates and rising home prices.

But if it was easy to ignore the complaints of scholars and advocates for working-class families and communities of color, it would prove more difficult to brush aside the concerns of the armada of securities analysts and bond traders working to protect the interests of capital. Most American home loans are securitized almost immediately: banks and mortgage companies make loans, then sell the obligations (and sometimes the 'servicing' rights) to investors in return for a fresh infusion of capital that can be used to make more loans. In the conventional, prime market, loans are typically sold to one of the giant Government Sponsored Enterprises (GSEs), Fannie Mae or Freddie Mac; but the subprime market is dominated by private trusts and Special-Purpose Vehicles (SPVs) that acquire loans, pool them into packages of Mortgage-Backed Securities (MBSs) that are underwritten by Wall Street investment banks. MBS shares are often held by national banks' off-balance sheet Structured Investment Vehicles (SIVs), and are also traded in various risk categories ('tranches') to individual and institutional investors on Wall Street and other global financial markets. Since the mid-1990s, the specialized field that spawned all these acronyms - structured finance - seemed to have achieved financial alchemy, packaging individually risky subprime loans into high-yield MBSs that scored the highest, triple-A grades from bond-rating agencies (Dymski 2007; Engel and McCoy 2007; Fabozzi 2001; Peterson 2007). In a climate of steadily rising home values, even the most egregious predatory schemes involved surprisingly low risks for investors, since borrowers who fell behind on their payments could be forced into a quick refinance -- generating new up-front fees charged against the borrower's home equity -- or into a quick distress sale to pay off the debt without entering foreclosure. Brokers and bankers continued to enjoy healthy profits from up-front fees and charges, lenders earned healthy margins on sales to the secondary market, and once borrowers' repayment capacity or home equity was stripped bare, loan servicers would force sales to protect MBS investors from losses. The only consistent losers were the homeowners stripped of their assets and now looking for homes to rent.

This system worked well for brokers, lenders, investment banks, bond-rating analysts, and investors. Subprime originations mushroomed from $\$ 65$ billion in 1995 to $\$ 332$ billion in 2003 (Chomsisengphet and Pennington-Cross 2006: 37), and then to $\$ 625$ billion in 2006 (Andrews 2007c). These capital flows were simultaneously diffuse -- loans made in neighborhoods across America were securitized for shares sold to investors around the world -- and narrowly channeled through particular actors with specialized legal and financial expertise: since 2000, a single Wall Street law firm, McKee Nelson, helped investment banks prepare securities filings for more than three thousand MBS deals worth some \$2.7 trillion (Browning 2008). Brokers and lenders became ever more aggressive in searching for borrowers who could be coaxed, cajoled, or simply tricked into taking out a loan to do home repairs, to pay off credit card or medical debts, or to refinance a previous mortgage. Finally, though, in late 2006 the cadres of Wall Street analysts glimpsed the limits to subprime capital, as innovative aggression and competition had accelerated even after home prices had stalled in the previous year. Speeds accelerated for delinquencies, defaults, and foreclosures. The cohort of loans made in the fourth quarter of 2006 fell behind on payments within months, a pace faster than analysts had ever seen. In early February, 2007, the upscale British banking empire HSBC issued an "unprecedented profit warning" (Tam 2007) thanks to the troubles of its notorious U.S. based subprime subsidiary -- a 
unit acquired five years earlier in a move that shocked the business press for the potential to stain an otherwise "squeaky clean," very "Presbyterian" reputation (Sorkin 2002). HSBC struggled to reassure anxious investors by emphasizing that the trouble was confined to U.S. operations, and even more narrowly limited to the faster-than-expected defaults of subprime loans issued only a few months earlier. This was not the most reassuring message for bond traders already nervous after former Federal Reserve Chairman Alan Greenspan had used the word "recession" in a private chat by satellite with Hong Kong investors (Andrews 2007a) and after rumors of a Chinese government crackdown on debt-financed stock purchases bled nine percent off the Shanghai index on February 27. When the Dow fell 415 points the next day, Wall Street analysts quickly blamed the troubles in America's subprime mortgage sector. The once-obscure "subprime" suddenly became a fixture of front-page, above-the-fold coverage of investor anxieties spreading around the globe. At first, bankers and officials expressed faith that the damage was contained: in March and again in May, the new Fed Chairman Ben Bernanke reassured Congress that the subprime crisis would not bleed into the broader economy (Andrews 2007a, 2007c), an assurance that he repeated for several months until the spreading disaster undermined his own confidence in the mortgage industry's practices (see Bernanke 2007: 2-4). One investment strategist offered an early warning of unknown unknowns: "It is impossible to get a number" on investment banks' subprime vulnerability, “...And I don't think they even know" (Anderson and Bajaj 2007: C1). Stock-index gyrations mesmerized the business press for months as the phrases "global credit crisis" and "subprime mortgages" fused together in the lead paragraphs of hundreds of stories explaining the finer points of structured finance -- MBS yields, risk tranches and 'mezzanine' securities, collateralized debt obligations (CDOs), and CDOs of CDOs (known among the literati of structured finance as CDO-squared). Front-page news coverage also introduced a broad new audience to the detailed terminology -- long familiar to researchers, attorneys, and community activists -- of subprime industry practices used in so many low-income and racial minority communities: prepayment penalties, penalty interest rates, yield-spread premiums, balloon payments, flipping, stripping, negative amortization, hybrid adjustable-rate mortgages (aptly dubbed HARMs), and the especially creative mortgage marketed as the NINJA loan (no income, no job or assets) (Perlstein 2007; see also Renuart 2004).

The situation worsened after November, 2007. At high-level economic talks in Xianghe, Chinese officials told their American counterparts that "the subprime mortgage crisis that has shaken the U.S. economy and the weakening dollar are as much a problem for the global economy as Chinese exchange rates." (Cha 2007). "Tables Turned: Poor Countries Wag Fingers at Rich Ones." (Weisman 2007). The OECD cautioned that the $\$ 50$ billion in U.S. mortgage writedowns announced by financial institutions up to that point was only the beginning, and estimated that total losses could reach $\$ 300$ billion (Dougherty 2007). Beginning in late November, 2007, corporate earnings reports delivered a machine-gun barrage to market confidence, as investors and analysts realized the impossibility of assigning meaningful values to the intricate MBS shares, CDOs, and credit default swaps manufactured by the industry of promises and commitments among financial institutions: as fourth-quarter results trickled in, the top of the heap of the writedown wreckage included Bank of America ( $\$ 7.9$ billion), Morgan Stanley (9.4), HSBC (10.7), UBS (18.4), Citigroup (22.1), and Merrill Lynch (24.5) (Bloomberg 
2008: C6). ${ }^{1}$ The Fed joined forces with central banks in Canada and Europe to infuse \$64 billion in short-term credit in an attempt to encourage lenders to trust one another again; markets rallied a bit when the European Central Bank raised the stakes with a full half a trillion dollars to ease liquidity shortages during the holiday, although the Governor of the Bank of England "conceded ... that the central banks, despite their ability to manufacture unlimited amounts of cash, are reaching the limits of their ability to ease the five-month old credit crisis." (Dougherty 2007b: C5). Bargain-shopping began. Countrywide Financial, the nation's largest mortgage lender in the previous year, was gobbled up by Bank of America at a steep discount. Bear Stearns got a $\$ 1$ billion infusion from China's state-controlled Citic Securities, Citigroup sold parts of itself to raise \$7.5 billion from the Abu Dhabi Investment Authority, and weeks later $\$ 12.5$ billion from the Kuwait Investment Authority, the Singapore Investment Corporation, and several other investors. Merrill Lynch raised $\$ 6.6$ billion from the Kuwait Investment Authority, the Korean Investment Corporation, and others, while UBS sold a ten-percent stake to the Singapore Investment Corporation and anonymous investors from the Middle East. Morgan Stanley secured $\$ 5$ billion for a 9.9 percent stake by the China Investment Corporation. The Chief Financial Correspondent of the New York Times dryly observed that "The financial market crisis of 2007 may be remembered as the beginning of the nationalization of a large part of the financial system" (Norris 2007: C1) -- in truth, a transnationalization, or what former Treasury Secretary Lawrence Summers dubbed "cross-border nationalization," driven by sovereign wealth funds scouring the wreckage of the American banking system for buying opportunities.

\section{Market Imperfections and the Flat Subprime World}

Amidst the disorienting worldwide maelstrom of business-press coverage, it is easy to overlook two foundational axioms that have framed mainstream discussion and public policy; these assumptions are the focus of our analysis. First, the collapse of subprime securitization is assumed to result from regrettable but unpredictable mistakes and "market imperfections" (Federal Reserve 2007: 14) in the complex financial instruments connecting subprime borrowers to transnational capital markets. Everyone has been hurt, the argument goes, in the "chain of misery" (Landler 2007) that stretches from inner-city homeowners facing foreclosure, to suddenly-unemployed mortgage brokers, bankrupt mortgage companies, depositors in British and German banks, investment bankers liquidating hedge funds with subprime exposure, individual investors holding bank stocks now shunned as "subprime slime" (Henderson 2007), and all the way to residents of tiny Narvik, Norway, who face deep budget cuts after municipal investments lost at least $\$ 64$ million in complex securities backed by American subprime loans (Landler 2007). These are unusual circumstances, the axiom holds, but there is nothing fundamentally wrong with the innovations of subprime lending or structured finance. These innovations of "risk-based pricing," the argument goes, had finally solved the credit rationing problems of exclusion and racial redlining -- thus expanding access to credit and the American Dream of homeownership for low-income and minority families (for the clearest summary of this view, see Litan 2001). The subprime boom just went too far, the industry's defenders claim, because brokers and lenders tried to help too many consumers who were more than willing to borrow beyond their means. Put simply: mistakes were made, borrowers must accept their share

\footnotetext{
${ }^{1}$ As of late January, 2008, U.S.-based financial institutions had written off a total of $\$ 146$ billion, about $\$ 135$ billion of it backed by subprime mortgages (Bloomberg 2008).
} 
of responsibility, and the market must be allowed to adjust with the absolute minimum degree of public intervention.

The second axiom holds that geography is empirically interesting but theoretically irrelevant. To be sure, the subprime boom has etched out intricate urban and regional patterns; even the most conservative major newspaper in America, the Wall Street Journal, compiled detailed rankings and maps of "The United States of Subprime" (Brooks and Ford 2007), and published an indepth analysis of billions of dollars of subprime capital "injected" into a middle-class Black neighborhood in Detroit (Whitehouse, 2007). But these patterns are almost always understood as nothing more than the result of demand-side factors -- the needs, preferences, qualifications, or education of homeowners and homebuyers, or the distinctive circumstances of particular places. Yes, conservatives acknowledge, places like Detroit are drowning in waves of foreclosures after years of subprime market penetration; but this is simply because Detroit is a special (basket) case, where consumers would be entirely excluded from credit were it not for the opportunities of subprime loans. From day to day, the geographical details of this narrative change: 'ground zero' of the nation's crisis is Ohio's rustbelt Youngstown, Cleveland, and Akron (Birchall 2007), or Stockton, California (China Daily News 2007), California's Riverside County (Brenoff 2007) or Memphis, Tennessee (Ferguson 2007). But the logic remains the same. The spatiality of subprime credit is assumed to be a Pareto-optimal response to the geography of demand among consumers unable or unwilling to meet the standards for the prime market. Put simply, after controlling for consumer qualifications, the subprime world is flat (cf. Friedman 2007).

In the rest of this paper, we provide a challenge and an alternative to these two foundational axioms. Subprime lending exploits the legal and regulatory loopholes justified by risk-based pricing in order to provide opportunities to realize class-monopoly rent. Even after accounting for the qualifications and risk profiles of borrowers, subprime America is anything but flat: credit flows etch out intricate urban and regional geographies of class-monopoly rent that are rooted in generations of racialized inequalities currently being redrawn by immigration and regional economic change. Our story unfolds in five parts. First, we review the theories of credit rationing and risk-based pricing, which provide the dominant economic and policy explanations for the subprime boom and its associated racial-geographical disparities. Second, we explain how contemporary inequalities in the subprime market should be understood not as market "imperfections," but as latter-day incarnations of Harvey's (1974) class-monopoly rent. Third, we describe a protocol for measuring and mapping the racial and class dimensions of class-monopoly rent. Fourth, we use this protocol to map the geography of the subprime boom at its peak (2004-2006) across several hundred metropolitan areas in the U.S.; we use several approaches to test whether variations in market penetration simply mirror borrower qualifications (as predicted by risk-based pricing), or reflect more systematic inequalities (as suggested by class-monopoly rent). Finally, we map some of the new spaces being created by analysts, advocates, and attorneys in the Community Reinvestment Movement.

\section{Rationing, Risk, and Race}

Credit is fascinating for economists (and especially neo-classical economists), because it is vulnerable to a dilemma first identified by Adam Smith. If the interest rate is set too high, 
“...the greater part of the money to be lent, would be lent to prodigals and profectors.... Sober people, who will give for the use of money no more than a part of what they are likely to make by the use of it, would not venture into the competition." (Wealth of Nations, 1776, cited in Stiglitz and Weiss 1992: 694).

Two centuries on, we still have prodigals and profectors: "The fundamental problem facing capital markets can be put starkly: there is an infinite supply of charlatans in the market...." (Greenwald and Stiglitz 1991: 8). Charlatans disrupt the entire system, because credit is not like other commodities: money circulates not for current goods and services, but in exchange for contingent promises about the future that take the form, "I will pay a certain amount, provided that I can; and if I can't, other consequences follow...." (Greenwald and Stiglitz 1991: 5). ${ }^{2}$ The dilemma becomes intractable under conditions of asymmetric information, when lenders do not have enough information to know borrowers' true abilities or intentions to honor their debts. In this situation, a perverse problem of adverse selection sets in when lenders raise the cost of credit to cover the expected losses on borrowers who appear to be more risky. The higher price will deter the prudent borrowers who will work hard to honor the debt, but it will not discourage the charlatans who have no intention of repaying the obligation. ${ }^{3}$ If lenders do not have enough information to distinguish between these good and bad risks, they will over-react by setting qualification standards too high, they will resort to idiosyncratic or irrational criteria in attempts to avoid the charlatans, and they will ration credit on supply rather than price. The result is a systemic credit shortage for many qualified borrowers (Stiglitz and Weiss 1981).

Credit rationing is the dominant neoclassical explanation for the exclusionary, racial redlining and discrimination that plagued American cities for generations, through the 1980s (Berkovec et al. 1994; Litan 2001; Stiglitz and Weiss 1981; Vandell 1984). If the ontological appeal of the theory for conservatives is obvious (inequalities result from something other than the racist bigotry of lenders), so is the solution: get more and better information on consumers to eliminate information asymmetries. As lenders are able to acquire more relevant and reliable information to help distinguish borrowers with good and bad intentions, they will once again be able to use the price mechanism to allocate credit more efficiently to more people. This expanded information and analytical screening capacity finally arrived in the 1990s, with a revolution in consumer credit reporting and surveillance systems, credit scoring algorithms, automated underwriting software, and finely-tuned delinquency and default models (Miller 2003; Saunders and Allen 2002; White 2002). For conservatives, the entire subprime boom that began in the mid-1990s represents a triumph of risk-based pricing: expanded access to credit for 'weaker'

\footnotetext{
${ }^{2}$ To appreciate how large these contingent promises have become, it helps to recall that Greenspan's response to the $\$ 200-\$ 400$ billion in subprime assets vaporized was to remind us that thanks to the "extraordinary" growth of globalization, "arbitragable long-term assets are close to a hundred trillion dollars" worldwide (Greenspan 2007). A few weeks before Greenspan's interview, the U.S. Treasury announced that the U.S. national federal debt had exceeded the $\$ 9$ trillion mark for the first time. A few days after Greenspan's remarks, "provided that I can" became "I might not be able to" as Merrill Lynch, Bear Stearns, and other banks began to plan a bailout for a bond insurance company the banks had paid to hedge against their mortgage losses; one observer echoed Greenwald and Stiglitz' (1991) logic: "It's a zero-sum game.... If you put trades on that worked so well that you bankrupt your counterparty, you will not collect on your trades." (Bajaj and Morgenson 2007: C4). As of June, 2007, the total value of all credit default swaps was \$42.6 trillion, seven times the figure at the end of 2004 (Bajaj and Morgenson 2007: C1).

${ }^{3}$ In other words, lenders quickly discover that the paramount instrument of classical economic theory -- the price mechanism -- fails to clear markets or maximize profits, and instead worsens the situation.
} 
borrowers and racial/ethnic minorities, with competition among lenders ensuring that the added cost of credit is just enough to provide a 'normal' rate of profit after covering the increased losses incurred in serving the more risky consumers. Risk-based pricing fits smoothly into the parallel deep grooves of both defensive, roll-back neoliberal deregulation, as well as offensive, entrepreneurial roll-out neoliberal innovation (Peck and Tickell, 2002). Expanded access to credit, at a higher but justifiable price, offers the rising financial tide that will lift all boats.

For at least two decades, risk-based pricing has been the central doctrine of America's deregulatory policy stance on financial services. There is now a compelling body of evidence that contradicts the rosy predictions of the theory. Most of this evidence comes from specialized empirical and legal analysis of actual industry practices (for reviews, see Engel and McCoy 2002, 2007; White 2004). ${ }^{4}$ Unfortunately, much of this research challenges only the empirical predictions of risk-based pricing -- not its underlying philosophy or meaning. Risk-based pricing thus retains its enormous popular acceptance: it seems only logical and reasonable that lenders should be encouraged to serve people in need, and be allowed to charge rates tailored to the risk of consumer default. ${ }^{5}$ Even in the midst of the current catastrophe, many progressives fall into the trap set by conservative advocates of risk-based pricing -- accepting the presumptions that a) subprime lenders got into trouble because they were too generous with risky borrowers, and b) attempts to regulate the industry will discourage lenders from serving low-income and minority consumers, thus hurting those we wish to help. Beneath these assumptions lies the bedrock, bipartisan policy consensus that deregulated financial markets are the only way to allow all households an opportunity to achieve the "American Dream" of homeownership.

Unfortunately, the material meaning of homeownership has shifted dramatically in recent years, particularly for the poor and the working classes. Millions of "owners" have only the most precarious ability to "have, possess" according to the etymology of the Old English ägnian and agen. Many owners are in fact renters. Capital is the landlord.

\footnotetext{
${ }^{4}$ A few examples include studies documenting a) how lenders and brokers hide important information about complex loan instruments from borrowers -- thus reversing the information asymmetries at the heart of creditrationing theory, b) that expenses justified in theory as compensation for long-term risk are in fact pursued as shortterm profit, and c) the problems of adverse selection are not limited to borrowers, but also the many charlatan brokers, lenders, and other actors on the supply side.

${ }^{5}$ One among countless recent examples: "innovative loan options" are serving people and places who would otherwise be excluded from credit, as the President of the National Association of Mortgage Brokers put it in Senate Testimony, and thus legislators should avoid any temptation to regulate lending terms or practices - they should "not risk 'turning back the clock' to a pre-Fair Housing Act era where certain population segments were unfairly denied access to loan financing options." (Dinham, 2007, p. 10). Any restriction on the freedom of brokers and lenders to arrange any kind of "innovative loan option" will threaten consumer sovereignty -- "Only the consumer can determine the "best' combination of factors that fit their needs" - and will "upset the balance created by the market that provides homeownership opportunities to so many Americans" (Dinham, 2007, p. 9). While Dinham and others provide the wholesale version of risk-based pricing, columnists like David Brooks offer the mass-market retail version - applauding an innovation that is just going through a "painful adolescence." But "in most cases, the market corrects itself" in a "complex ecosystem" where "everyone seeks wealth while minimizing risk." (Brooks 2008: A27). "Two Cheers for Wall Street."
} 


\section{Renting Capital}

If risk-based pricing and credit rationing boast a genealogy to the great Adam himself, so does the theory of class-monopoly rent:

"The rent of land, considered as a price paid for the use of the land, is naturally a monopoly price. It is not at all proportioned to what the landlord may have laid out upon the improvement of the land, or to what he can afford to take; but to what the farmer can afford to give." (Wealth of Nations, 1776, cited in Evans 1991: 2).

For unimproved land, the cost of 'production' for the landowner is zero, and yet still the owner receives a price for its use; the class of landowners, by definition, enjoy a monopoly that commands rent. This insight was "a feature of classical economics" (Evans 1991: 4) in the eras of Ricardo, Smith, Mill and Marx; but it "virtually disappears from the literature" (p. 3) after Marshall popularized the use of "economic rent" to describe any kind of excessive payment to any factor of production. "Class" was erased from the economics and rent literatures from the early twentieth century until Harvey's (1974: 240) eloquent reminder of the inescapably social relations of tenure:

"Tenants are not easily convinced that the rent collector merely represents a scarce factor of production. The social consequences of rent are important and cannot be ignored simply because rent appears so innocently in the neoclassical doctrine of social harmony through competition."

Through the 1960s, considerable attention focused on the adaptation of agricultural land-rent theory -- especially differential land rent -- to understand the spatial structure of cities; Harvey, however, understood class-monopoly rent as conceptually distinct from differential rent; ${ }^{6}$ all three of the constituent words in the phrase are crucial. Class matters because in all capitalist societies, the rights and privileges of ownership are important correlates of class power and social inequality. Monopoly matters not primarily because the supply of land is limited, ${ }^{7}$ nor because landowners can (under certain circumstances) become price-makers, but rather because of the inherent monopoly associated with the legal status of ownership: owners enjoy a collective power in the marketplace by virtue of the fact that they are not renters. ${ }^{8}$ Owners'

\footnotetext{
${ }^{6}$ Evans (1991) draws careful distinctions between 1) class monopoly, 2) site monopoly, and 3) 'Marxian monopoly rent,' the latter distinguished from Marx's categories of 4) differential and 5) absolute rent. Categories 1) and 5) are closely related, as are 2) and 4), while 3) is Evans' central concern. Our theorization relies on a fusion of 1) and 5).

${ }^{7}$ Supply constraints are quite flexible in urban areas, with expansion upward (high-rise construction) and outward (harbor fill, river floodplain reclamation, swamp fill) both permitting the creation of new urban land.

${ }^{8}$ Owners do rent at times, of course, and tenure should never be used as a definitive, static way of dividing all parts of society into either/or; individuals follow complex trajectories of class relations and property ownership based on early family life, experiences in education the labor market, family decisions, and many other factors associated with economic success and housing needs. But when landlords see the value of the owner/renter binary devalorized, they are clearly angry. Amidst the intensified polling in advance of the 2008 U.S. Presidential election, the New York Times interviewed Robert W. Jennings, a Kansas City landlord who was forced to take an hourly job at Home Depot to keep up with the mortgage payments on his rental building when the adjustable-rate loan reset upward. " 'I used to be master of my universe,' he said from a bar stool at McCoy's Public House. 'Now I work for this soulless corporation. I used to make the rules. Now I have to follow them."” (Sack 2008: A16).
} 
rights are codified in law, backed up by state protection -- and, if necessary, the threat of police violence. State protection is by no means absolute (as made clear in the Supreme Court's Kelo decision) but it is much more valuable than the minimal security available to renters. Finally, rent is the simple yet crucial economic measure of the claim that owners can make on those who use their resources. Most analysts have examined this claim primarily for land, rather than the improvements thereon: a rich tradition stretches from Marx and Smith (Adam) all the way to contemporary rent-gap research inspired by Smith (Neil). But it is not necessary to distinguish between land value and house value in order to appreciate the significance of owners' claims on the use of any capitalizable asset:

"The concept of 'class-monopoly rent' describes any situation in which the rate of return to a class of providers of an urban resource (such as housing) is set by the outcome of a conflict with a class of consumers of that resource." (Harvey 1974: 239).

These conflicts are mediated by the various kinds of financial institutions providing credit for those who can only become owners through mortgage debt: "All of these institutions ... operate together to relate national policies to local and individual decisions and, in the process create localized structures within which class-monopoly rents can be realized." (Harvey 1974: 245).

For empirical illustration, Harvey mapped the anatomy of class-monopoly rent in neighborhood submarkets of Baltimore, Maryland. Although part of his analysis dealt with conflicts between speculator-developers and suburban middle- and upper-income homebuyers, the most shocking exploitation was apparent in the urban core, where urban and regional context inscribed localized variations on the deeply entrenched and fundamentally American dilemma (Myrdal 1944) of White racism against African Americans. In one inner-city submarket, home and land sales were "dominated by cash and private loan transactions with scarcely a vestige of institutional or government involvement in the used housing market" (245). The most severe class-monopoly rent inequalities in this submarket follow the landlord-tenant binary, as mediated by American urban racism: "Professional landlords are anxious to disinvest" from real estate so they can earn higher returns in the financial markets,

"but they still manage to get a rate of return around 13 percent.... The tenants are low-income and for the most part black. They are poorly organized, exercise little political control and are effectively trapped in this sub-market. Class-monopoly rents are here realized by professional landlords who calculate their rate of return to match the opportunity cost of capital." (p. 245).

In a separate submarket of West Baltimore, by contrast, lower-middle class blacks had sufficient incomes to consider homeownership. Yet they faced discrimination and exclusion from mainstream financial institutions, and could only gain access to ownership through the landinstallment contract:

"A speculator purchases a house, ... adds a purchase and sales commission, various financing charges and overhead costs, renovates and redecorates the property and finally adds a gross property margin of, say, 20 percent. ... To 
finance the transaction [for a black buyer], the speculator interposes his credit rating between that of the purchaser and the financial institutions. ... The speculator retains title to the property ... but permits the 'buyer' immediate possession." (p. 245).

Only after several years of payments could a 'buyer' reduce the principal enough to obtain conventional financing and achieve 'true' ownership. These types of schemes spread throughout scores of U.S. cities in the 1960s, and allowed speculators to charge steep premiums to African Americans excluded from mainstream credit flows.

"Blacks consequently regarded themselves as exploited and paying 'the Black tax,' which was nothing more nor less than class-monopoly rent realized by speculators as they took advantage of a particular mix of financial and governmental policies compounded by problems of racial discrimination." (p. 246).

\section{Subprime Lending as Class-Monopoly Rent}

The fundamental essence of the subprime lending boom -- whether it is applauded as benevolent risk-based pricing, or attacked as predatory exploitation -- involves the use of "homeownership" to connect national and transnational capital markets to the lucrative profit margins of the local class-monopoly rents analyzed by Harvey (1974). Two long-term shifts established and strengthened these connections. First, a durable bipartisan Washington consensus on the virtues of homeownership has steadily undermined rental housing markets, especially for low-cost units; with very few exceptions, federal tax and fiscal policies since the mid-1970s have made rental properties significantly less attractive for landlords -- encouraging passive disinvestment while worsening conditions for low-income tenants. Low-income homeownership, by contrast, has enjoyed support across the political spectrum, because of its presumed ability to enhance empowerment, strengthen communities, promote personal responsibility, and [insert any of the other fashionable policy mantras of neoliberal/neoconservative discourse] (see Retsinas and Belsky 2002). Second, deregulated financial innovation and creative debt management became key instruments of privatized public policy. Especially in housing, spending and redistribution policies were downplayed in favor of a new emphasis on tax credits and other incentives to encourage market-based solutions. This shift was bipartisan, too: Reagan championed regressive tax cuts, while Clinton permitted unprecedented banking-sector consolidation while using a combination of deregulatory carrots and fair-lending enforcement sticks to prod private markets to do mildly liberal things -- like providing more credit to low-income and minority borrowers (Listokin et al. 2000). The financial services industry had already begun searching for new market opportunities as growth rates moderated among its traditional demand base, and Wall Street was creating an ever-broader array of new kinds of credit default swaps and assetbacked securities markets for every conceivable debt instrument (Fabozzi 2001). After the landmark deficit-taming budget deals of the first year of the Clinton Administration in 1993, years of historically low interest rates propelled a wave of increasingly flexible mortgage lending to low-income households, racial and ethnic minorities, Native Americans on reservation lands, and all sorts of other "new markets." 
But of course these markets were new only for mainstream financial institutions, and for Wall Street investment conduits. "Underserved" markets have long been familiar to slum landlords, speculators, loan-sharks, mortgage-fraud entrepreneurs, and foreclosure specialists. The primary achievement of a quarter-century of public policy and financial innovation has been the selective replacement and de-localization of the individual actors described by Harvey: yesterday's local landlords and speculators financed by local or regional banks have been replaced by today's network of local brokers, working independently or for various kinds of non-bank mortgage companies or bank subsidiaries, nearly all of them selling the loans to obtain fresh capital flows from private investors and SPVs working with national lenders and Wall Street investment banks.

Since the 1970s, the individual actors have changed; but the material relations of exploitation are the same. Today, fewer inner-city African American renters are forced to pay class-monopoly rent to slum landlords, and fewer aspiring black homeowners are forced to accept the terms of speculators peddling land installment contracts. But many more African Americans (and Latinas and Latinos, and others) are pushed into high-cost subprime mortgage credit -- even when they are qualified for better-priced prime credit, and often (in the case of home improvement and refinance loans) when they are not even seeking credit in the first place (Peterson 2005; Renuart 2004; Squires 2004). ${ }^{9}$ Anyone trapped in the web of high-cost subprime credit is forced to pay a wide range of interest-rate premiums and complex fees and charges, many of them carefully disguised. These excessive payments are sustained by information asymmetries (the econometric term for deception) and by savvy exploitation of many consumers' belief that they will be unable to qualify for mainstream credit from a traditional bank. The excessive payment stream is allocated, by negotiation as well as competition, amongst brokers, lenders, appraisers, home-improvement contractors, investment banks, and investors seeking maximum risk-adjusted yields in MBS shares. All of these actors have, for the most part, replaced the slum landlords and land-installment speculators of a previous age; they all derive their income from their function in the division of labor that sustains the circulation and accumulation of subprime mortgage capital. Home "owners" drawn into the subprime system are, in material and housingclass terms, barely distinguishable from renters: laboring under oppressive debt ratios, with little accumulated home equity, borrowers who encounter financial difficulties are only a few months from the start of foreclosure proceedings -- not much different from renters in financial distress. In the subprime market, homeowners are simply paying rent to the new landlord, subprime mortgage capital. In these circumstances, the cultural symbolism of homeownership is nothing more than a deceptive illusion: "If the mortgaged homeowner doesn't pay the mortgage, he's out. And if the renter doesn't pay the rent, she's out. When the crunch comes, owning and renting are not so different." (Krueckeberg 1999: 23).

\section{Hypotheses}

Our perspective on class-monopoly rent is nothing new. Its basic outlines were sketched clearly by Harvey in 1974, with refined extensions and implications elaborated in the subsequent decade

\footnotetext{
${ }^{9}$ Approximately one-half of the interest-rate premium paid by subprime borrowers "cannot easily be explained by the higher levels of risk associated with these types of loans" (Lax et al. 2004: 569), and large-scale studies have suggested that up to half of all borrowers with subprime loans could have qualified for prime credit (see Stein 2001: 10).
} 
(Harvey 1978, 1981, 1985). Our theory is implicit in, and complementary to, other lines of inquiry in a rich literature, including historiographies of the Community Reinvestment Movement (Squires 1992, 2003, 2004), legal-economic diagnoses of segmented subprime credit markets and global finance (Engel and McCoy 2002, 2007), long-term measures of the transformation from the old inequalities of exclusion to the new inequalities of stratified inclusion (Ashton 2008; Immergluck 2008; Williams et al. 2005), and especially Peterson's (2007) notion of "predatory structured finance" and Gotham's (2006) Harvey-inspired analysis of MBSs as the secondary circuit of capital. Our perspective also aligns with attempts to measure the total costs of the subprime sector: Stein (2001) estimated that excessive interest premiums, equity stripping, and other legal-but-unethical practices extract at least $\$ 9.1$ billion annually from subprime borrowers, while Rivera et al. (2008) estimate the total housing wealth stripped out of Black and Latino communities was between $\$ 164$ billion and $\$ 213$ billion between 1998 and 2006. Our purpose is to add an explicit, consistent, and multivariate urban and regional dimension to this literature. If we were to map Harvey's (1974) relations of classmonopoly rent as it circulates through Berry's (1964) cities as systems within systems of cities, what would we see in this cartography of capital?

We propose three hypotheses, which we evaluate during the peak of the subprime boom from 2004 to 2006. First, a metropolitan market penetration hypothesis begins with the risk-based pricing notion that subprime credit will be most common in places marginalized by urban and regional inequalities of deindustrialization and uneven development. Even after accounting for these factors, however, we hypothesize that the geography of race and ethnicity still matter: in the distorted world of subprime marketing, targeting racially and ethnically marginalized communities is an efficient, economically rational way to find consumers who feel excluded from mainstream credit markets, and who are likely to be more vulnerable to deception and abuse. Second, a racial-geographic segmentation hypothesis proposes that class-monopoly rent provides a more convincing explanation than risk-based pricing for credit market outcomes among individual borrowers. We adopt the simple legal logic of burden of proof: if observed racial disparities in subprime lending cannot be fully explained by the incomes and risk profiles of borrowers, then the burden of proof shifts to the supply side - in particular, the evolving competitive position of various types of lending institutions quickly selling their loans to different kinds of secondary-market purchasers and investors. Even after accounting for these institutional divisions and the characteristics of borrowers, however, is there any evidence that the new "black tax" of subprime class monopoly rent varies significantly across the urban system? We do find some variation, and this suggests a third hypothesis on what we describe as an urban system of mobilization. For many years, the diverse coalitions of progressives in the Community Reinvestment Movement (Squires 1992, 2003, 2004) have used research, organizing, and litigation to fight against the real, material injustices of American mortgage capital - from the discriminatory exclusion of old-style redlining (Squires 1992) to the newer discrimination of stratified inclusion of racially-biased, exploitative subprime lending (Squires 2003, 2004). We suggest that the movement's achievements should be understood as much more than a series of tactical engagements: mobilization against the "real" urban system of classmonopoly rent has created another urban system - just as real - of organizational, institutional, and legal assets that offer the promise for greater fairness in access to capital. This new, progressive urban system remains vulnerable to the structural inequalities of American mortgage 
capital, but it is an extremely valuable social construction. We map a few of the systems within systems of organizing, research, and litigation across this urban and regional network.

\section{Data}

Many different kinds of data sources provide complementary yet partial view of specific facets of the subprime market - from marketing and application dynamics to underwriting, loan origination, securitization, and longitudinal measures of prepayment, default, delinquency, and foreclosure (for a review of some of these data sources, see Immergluck 2008). But if we wish to measure the market consistently across nearly all cities and suburbs across the nation, the only comprehensive source comes from the annual application-level records reported by lending institutions that comply with the Home Mortgage Disclosure Act (HMDA) (FFIEC, annual). HMDA provides, inter alia, the requested loan amount, purpose, and income of each consumer applying for a mortgage loan from a covered lender, along with the location of the collateral property, the outcome of the application, and (for loans approved and originated) information on whether the loan was sold in the same calendar year to a secondary-market investor. HMDA has many well-documented limitations, but a) unlike specialized industry datasets, it provides unparalleled coverage of most of the market, b) unlike specialized housing surveys or internal lender files, it is a full enumeration rather than a sample, and c) it is the only comprehensive source of information on applicants' racial and ethnic identities for specific types of loans in particular places. Additionally, some of the limitations of HMDA ensure that it will understate the true extent of exploitation and bias. ${ }^{10}$ Beginning in 2004, expanded disclosure rules required lenders to identify originations classified as high-cost, or "rate-spread" loans - where the annual percentage rate cost of borrowing, including up-front points and fees, is more than three percentage points higher than the reported yield for U.S. Treasury securities of comparable maturity for first mortgages, and five percentage points higher for subordinate liens (see FDIC 2005).

\footnotetext{
${ }^{10}$ Lenders below specified size and lending activity thresholds are not required to report HMDA records. Some operators craft their business to escape disclosure requirements, while other fly-by-night shops simply refuse to comply. Between 2004 and 2006, the Federal Reserve cited almost 300 banks for violations of HMDA (Braunstein, 2007). Discriminatory and/or fraudulent practices are likely to be much more prevalent among institutions who refuse to disclose their activities.
} 


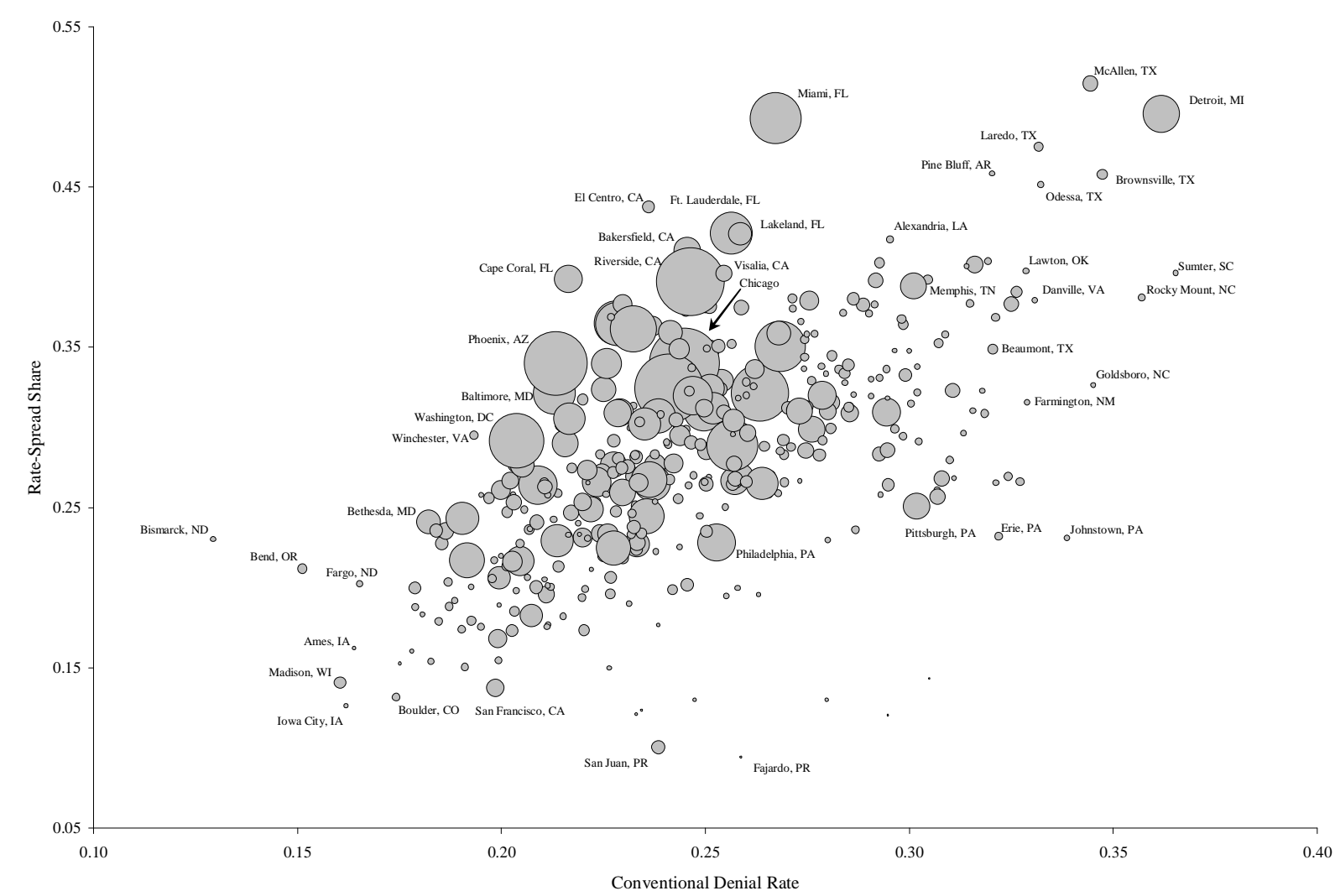

Figure 1. Denial Rate for Conventional Mortgage Applications, vs. Rate-Spread Share of Conventional Loan Originations, by Metropolitan Area, 2006. Circle sizes are proportional to the number of rate-spread originations (e.g., 618 in Iowa City, 72,022 in Miami, 124, 215 in Riverside, CA). Data Source: FFIEC (2007).

Consider a simple illustration of the interpretive dilemma between risk-based pricing and classmonopoly rent, as seen through the geography of HMDA data. Figure 1 presents a simple summary of rate-spread loan shares and conventional application denial rates across all of the nation's metropolitan areas (and also in the new small-town "micropolitan areas" defined by the U.S. Census Bureau). The common-sense understanding of risk-based pricing seems inescapable: subprime credit achieves the greatest market penetration where it is needed the most -- in cities where higher shares of applicants are turned away from conventional credit. Metropolitan denial rates alone account for more than one-third of the variance in subprime market share, from the worst-case scenarios of Detroit and Texas border cities (where rate-spread loans account for more than two out of five loans) to the best-case outcomes in small college towns like Boulder, Colorado, Madison, Wisconsin, Iowa City and Ames, Iowa - where only one out of seven loans is subprime. But if we account for denial rates and other factors associated with the logic of risk-based pricing, is there any evidence of the kinds of racial-geographic disparities predicted by class-monopoly rent?

To address this question, we narrowed the full database used for Figure 1 to make it possible to match lending information to other metropolitan characteristics. We also applied several qualitycontrol screens for individual application records in order to ensure precise measures that build 
in a conservative bias against any finding of race-class-geographical exploitation and discrimination. ${ }^{11}$ The final database provides information on 16.1 million applicants in 2004, and 17.4 million in 2006 (Table 1). Between 2004 and 2006, denial rates edged up slightly, a reminder that relaxed underwriting did not quite allow credit for "anyone this side of life support" (Stiglitz 2007); almost a quarter of requests in 2006, 4.1 million, were rejected. Yet among those who did get loans, the share exceeding the rate-spread trigger shot up from 16.6 percent in 2004 to 29.7 percent in $2006 .^{12}$ Lenders retained only a third of the loans they made, and sold the other two-thirds - with a growing share of secondary-market sales bypassing the GSEs in favor of a wide variety of private investor conduits. The dataset also confirms the deeply racialized character of the subprime boom (Table 2). Non-Hispanic Whites comprise an absolute majority of subprime borrowers, and the share of whites with high-cost loans jumped from 13 percent to 22 percent. But market penetration was far higher for Blacks and Latinos. The ratio of Black-to-White subprime share fell slightly, from 2.86 to 2.44 , but the secular expansion of subprime share meant that by 2006, an outright majority of all African American borrowers were pushed into high-cost loans. For Hispanics, the disparities with whites jumped from 1.95 to 2.07 .

\footnotetext{
${ }^{11}$ Metropolitan areas in Puerto Rico, where the industry operates in a distinctive legal regime, were excluded from the final database. We also excluded all files with missing or invalid information on income or location, applications for government-insured loans, records for multifamily properties or with no formal mortgage lien, and records with either validity or quality edit failures. We also excluded applications in many of the new micropolitan areas defined by the Census Bureau in 2004 - since it is not possible to match these records to the detailed socioeconomic and housing characteristics reported in the 2000 Census. Finally, we sought to distinguish the subprime crisis from other disasters: Tables 1 through 4 exclude applications on properties located in New Orleans and Houma, Louisiana, and Gulfport-Biloxi, Mississippi.

${ }^{12}$ These figures are nearly identical to the Wall Street Journal's analysis of the entire HMDA dataset, which involved no micropolitan area exclusions or linkages to 2000 Census definitions and data (Brooks and Ford 2007).
} 
Table 1. Action Taken on Loan Applications, 2004-2006.

Approved by lender, but not accepted by applicant

Denied by lending institution

Withdrawn

Closed as incomplete

Approved and originated

Total applications

Rate-spread loans

All others

Total originations

Held in portfolio

Sold to GSE

Sold through private securitization

Sold to commercial bank, savings bank, or savings association

Sold to life insurance company, credit union, or finance company

Sold to affiliate institution

Sold to other type of purchaser

Total originations

\begin{tabular}{rrrrr}
2004 & Share & & 2006 & Share \\
\cline { 5 - 5 } $1,233,253$ & & & & \\
$3,469,950$ & 21.50 & & $1,438,651$ & 8.25 \\
$2,240,413$ & 13.88 & $2,465,289$ & 14.13 \\
656,618 & 4.07 & 629,899 & 3.61 \\
$8,542,665$ & 52.92 & $8,792,672$ & 50.40 \\
$16,142,899$ & 100.00 & $17,444,762$ & 100.00 \\
& & & \\
$1,422,550$ & 16.65 & $2,611,646$ & 29.70 \\
$7,120,115$ & 83.35 & $6,181,026$ & 70.30 \\
$8,542,665$ & 100.00 & $8,792,672$ & 100.00 \\
& & & \\
$2,447,105$ & 28.65 & $2,805,347$ & 31.91 \\
$2,138,295$ & 25.03 & $1,561,259$ & 17.76 \\
176,637 & 2.07 & 578,185 & 6.58 \\
520,018 & 6.09 & 437,624 & 4.98 \\
699,604 & 8.19 & $1,156,270$ & 13.15 \\
531,885 & 6.23 & 635,219 & 7.22 \\
$2,029,121$ & 23.75 & $1,618,768$ & 18.41 \\
$8,542,665$ & 100.00 & $8,792,672$ & 100.00
\end{tabular}

Note: database includes only conventional, single-family applications with first- or subordinate liens, with no missing or invalid financial or locational information, that can be matched to metropolitan area data as described in text, and excluding loans purchased by reporting institutions.

Data Source: Federal Financial Institutions Examination Council (2005, 2007).

Table 2. Race/Ethnicity and Subprime Lending, 2004-2006.

\begin{tabular}{|c|c|c|c|c|c|c|}
\hline & \multicolumn{3}{|c|}{2004} & \multicolumn{3}{|c|}{2006} \\
\hline & & & -spread & & & Rate-spread \\
\hline & Rate-spread & All others & share & Rate-spread & All others & share \\
\hline Non-Hispanic White & 673,925 & $4,582,813$ & $\overline{12.8}$ & $1,145,948$ & $4,051,650$ & 22.0 \\
\hline Non-Hispanic Black & 217,811 & 375,624 & 36.7 & 435,478 & 375,915 & 53.7 \\
\hline Hispanic $^{1}$ & 233,438 & 700,283 & 25.0 & 553,839 & 660,871 & 45.6 \\
\hline Demographic information incomplete ${ }^{2}$ & 293,987 & $1,182,673$ & 19.9 & 422,832 & 803,428 & 34.5 \\
\hline Native American & 7,694 & 24,852 & 23.6 & 9,474 & 19,630 & 32.6 \\
\hline Asian, Hawaiian Native, Pacific Islander & 37,603 & 383,259 & 8.9 & 92,718 & 327,771 & 22.1 \\
\hline
\end{tabular}

\section{Results}

\section{Metropolitan Market Segmentation}

Our first hypothesis is that subprime credit proliferates in economically marginalized areas, but that such economic and risk factors cannot fully explain the sharp patterns of racial-ethnic inequality documented by so many researchers and journalists (Brooks and Ford 2007; 
Immergluck 2008; Rivera 2008). We aggregated the loan-level files to metropolitan-area summaries, and then matched the summaries to a standard set of measures of economic, housing market, and demographic variables from the 2000 Census; we also developed a simple proxy for overall credit risk - the share of denials where underwriters cited credit history as a reason. ${ }^{13}$

Risk-based pricing suggests that subprime lending should achieve greatest market penetration in areas with low incomes and poor credit -- and that holding these factors constant, subprime credit flows should reduce denial rates. Standard OLS regressions provide mixed and inconsistent support for these expectations. ${ }^{14}$ On the one hand, there is evidence that the subprime flood spread throughout the urban system: in 2004, a dozen simple measures can account for 77 percent of the variance in subprime share, but only 65 percent in 2006. Subprime shares also increase as expected in areas with higher denial rates, lower per capita incomes, and greater market shares of applicants rejected for bad credit. But even after accounting for these factors, racial segmentation remains crucial - and it worsened at the height of the boom. In 2004, a one standard-deviation increase in the metropolitan share non-Hispanic Black increases subprime market penetration by 0.32 standard deviations; this elasticity of racial inequality increased to 0.36 two years later. Subprime penetration showed no significant bias towards cities with large Latino populations in 2004 (after accounting for income and other controls in the models), but yields a 0.34 standardized beta in 2006 . For many years, subprime credit was most pervasive in African American communities (HUD-Treasury Joint Task Force 2000; Squires 2003), whereas predators found it more difficult to penetrate Hispanic communities and other minority ethnic niches. This seems to have changed rapidly as brokers and lenders responded to Wall Street pressures to find more "underserved" markets.

\section{Racial-Geographic Segmentation}

Aggregate measures of market segmentation are helpful in mapping the broad contours of credit inequalities, but precise measurements require the analysis of outcomes for individual borrowers. To evaluate our second hypothesis - that lending industry dynamics and class monopoly rent account for racially unequal credit better than risk-based pricing - we analyze the 8.54 million loans in the dataset that were approved and originated in 2004, and the 8.79 million for 2006. We use logistic regression, the standard workhorse of the banking and lending literatures, augmented with an instrumental variable technique that provides an estimate of the credit risk for each individual applicant (see Abariotes et al. 1993; Holloway 1998; Myers and Chan 1995). This instrument is derived from the stated judgments of underwriters and lenders on their reasons for refusing to make loans to certain applicants, and it thus provides conservative insurance against any results that would unfairly place blame on the lending industry; our instrumental variable model, estimated on a random sample of all applications, is quite good at predicting the characteristics of those viewed as unacceptable by underwriters (Table 3). We use the parameters from this bad-credit model to calculate a risk proxy for each of the applicants who

\footnotetext{
${ }^{13}$ HMDA does not provide credit history information for all applicants, but certain types of lenders are required to cite up to three reasons when they decide to reject an application. "Credit history" is one of nine options lenders can choose from.

${ }^{14}$ To conserve space, full results are not presented here. All multicollinearity tolerance statistics are well below problematic thresholds.
} 
eventually did receive loans, and then we estimate several models to measure the factors that distinguish those who wound up with high-cost, rate-spread loans.

Table 3. Model Fit Diagnostics for Credit History Instrument

\begin{tabular}{|c|c|c|c|}
\hline $\begin{array}{r}\text { Probability } \\
\text { Range } \\
\end{array}$ & $\begin{array}{r}\text { Number of } \\
\text { Applications } \\
\end{array}$ & $\begin{array}{r}\text { Average model- } \\
\text { predicted probability } \\
\text { of bad-credit rejection }\end{array}$ & $\begin{array}{r}\text { Actual proportion } \\
\text { rejected for } \\
\text { bad credit } \\
\end{array}$ \\
\hline $0.1-4.9 \%$ & 54,974 & 0.027 & 0.026 \\
\hline $5.0-9.9$ & 29,679 & 0.070 & 0.071 \\
\hline $10.0-14.9$ & 11,113 & 0.122 & 0.122 \\
\hline $15.0-19.9$ & 5,487 & 0.172 & 0.183 \\
\hline $20.0-24.9$ & 3,055 & 0.223 & 0.220 \\
\hline $25.0-29.9$ & 1,655 & 0.273 & 0.262 \\
\hline $30.0-34.9$ & 1,025 & 0.323 & 0.322 \\
\hline $35.0-39.9$ & 642 & 0.373 & 0.388 \\
\hline $40.0-44.9$ & 479 & 0.423 & 0.441 \\
\hline $45.0-49.9$ & 345 & 0.475 & 0.464 \\
\hline $50.0-54.9$ & 235 & 0.522 & 0.519 \\
\hline $55.0-59.9$ & 162 & 0.574 & 0.549 \\
\hline $60.0-64.9$ & 138 & 0.625 & 0.696 \\
\hline $65.0-69.9$ & 100 & 0.670 & 0.640 \\
\hline $70.0-74.9$ & 102 & 0.725 & 0.657 \\
\hline $75.0-79.9$ & 57 & 0.779 & 0.754 \\
\hline $80.0-84.9$ & 31 & 0.822 & 0.774 \\
\hline $85.0-89.9$ & 6 & 0.867 & 0.833 \\
\hline $90.0-94.9$ & - & & \\
\hline 95.0 - 99.9 & - & & \\
\hline
\end{tabular}

Note: Model estimated on a randomly-selected sample $(109,285)$ of all applications.

We estimated four models each for 2004 and 2006, beginning with 1) basic applicant financial measures, loan purpose, and demographic characteristics, then adding measures of 2) lending industry structure, 3) estimated credit risk, and 4) metropolitan housing market context (see Table 4). Five model results stand out. First, measures of fit declined slightly across all model specifications, attesting to the generalized spread of subprime credit throughout the market. Second, the effects of core underwriting measures weakened: odds ratios for income and income-to-loan ratios moved closer to unity, as various forms of high-cost loans became more common among middle-income borrowers struggling to cope with the high costs of many markets. The odds ratio for owner-occupancy fell, as subprime credit became more closely linked to investment and speculative purposes; but the effect (from 0.89 to 0.69; see Model 1) is not nearly as large as implied by press coverage of legions of speculative flippers using exotic loan instruments. Third, racial disparities worsened. For Blacks and Latinos, the results are striking across all specifications. Subprime disparities shot up from 3.5 to 3.8 for African Americans, and from 2.0 to 2.9 for Hispanic borrowers. Accounting for differences in lender type (Model 2) and estimated credit risk (Model 3) certainly reduces these inequalities: but even after giving every benefit of the doubt to lenders with an instrumental variable that itself captures disparate-impact racial discrimination, African Americans are 1.6 times more likely than non- 
Hispanic Whites to have subprime credit in 2004, and 2.3 times more likely in 2006 . For Latinos, the corresponding increase is from 1.1 to 1.9. This result aligns with the aggregate, metropolitan-level analysis, and confirms that the subprime boom consolidated African American segmentation even as the industry made new inroads into Latino communities. At the same time, the central plank to justify risk-based pricing slid away; in 2004, increasing the credit risk measure by one standard deviation increased the likelihood that a borrower received a subprime loan by a factor of 1.43; only two years later, this ratio slipped to 1.24.

The fourth finding confirms the crucial role of institutional processes and capital circuits in connecting individual borrowers to transnational investment networks. Subprime lending has traditionally been most common among small, thinly-capitalized independent mortgage companies, which disclose their activity to the U.S. Department of Housing and Urban Development (HUD), but escape the closer supervision of the four main banking regulators. Yet as the federal banking regulators "shrugged" when confronted with proliferating abuses (Andrews 2007c), many traditional banks began to pursue the profits of the subprime boom. In some cases, large banks acquired existing, profitable subprime lenders; this approach carried some reputational risks when gold-plated firms bought lucrative but notorious bottom-feeders (illustrated by especially controversial acquisitions by Citigroup and HSBC). In other cases, lenders established their own specialized subprime subdivisions. Either way, the result was the same: traditional banks and subsidiaries joined the independent mortgage companies in the search for new profit opportunities. The odds ratio comparing independent mortgage companies to large national banks regulated by the Federal Reserve (the reference category) fell from 1.92 in 2004 to 1.32 two years later (Model 3). Traditional, locally-oriented savings and loan institutions -- the survivors of yesteryear's S\&L crisis now reporting to the Office of Thrift Supervision (OTS) became almost indistinguishable from the national, Fed-regulated banks snapping up lucrative subprime operations. Moreover, as banking structures evolved to create new channels for subprime credit on the front end, the back end was also shifting, as lenders accelerated their sales to the secondary market. For quite a few years, the majority of home loans have been securitized; conventional, conforming prime loans have typically been sold to the GSEs, while other notes, including a growing share of subprime loans, were sold to other actors in the expanding secondary trading business. Until recently, however, most lenders held many of the non-conforming, non-traditional, or high-risk loans in their own portfolio for a year or more. This practice, known as "seasoning," was particularly important in the 1990s as secondary-market investors reacted cautiously to front-line lenders who were relaxing underwriting criteria in order to reach new markets: seasoning a loan for eighteen months reassured a purchaser that a homeowner who qualified at a high debt-to-income ratio could actually keep up with the payments (Listokin et al. 2000). Our analysis reveals that this practice changed dramatically between 2004 and 2006. In 2004, subprime loans posted low odds ratios for all types of secondary purchasers: compared to prime loans (which are commonly sold quickly to the GSEs), subprime loans were, overall, more likely to be held in portfolio long enough to stretch past the same-year sale reporting requirements of HMDA. But as investors flooded the MBS market and investment banks became more aggressive, front-line lenders responded with more loans, more risky loans, passed on to the secondary market more quickly. In 2006, a loan approved and sold to a private investor was 3.2 times more likely to be subprime compared to an otherwise identical loan that was held in portfolio past the end of the year. A loan sold to an "other type of purchaser" -- usually an SPV that packages the loans before 
Table 4. Subprime Segmentation Models.

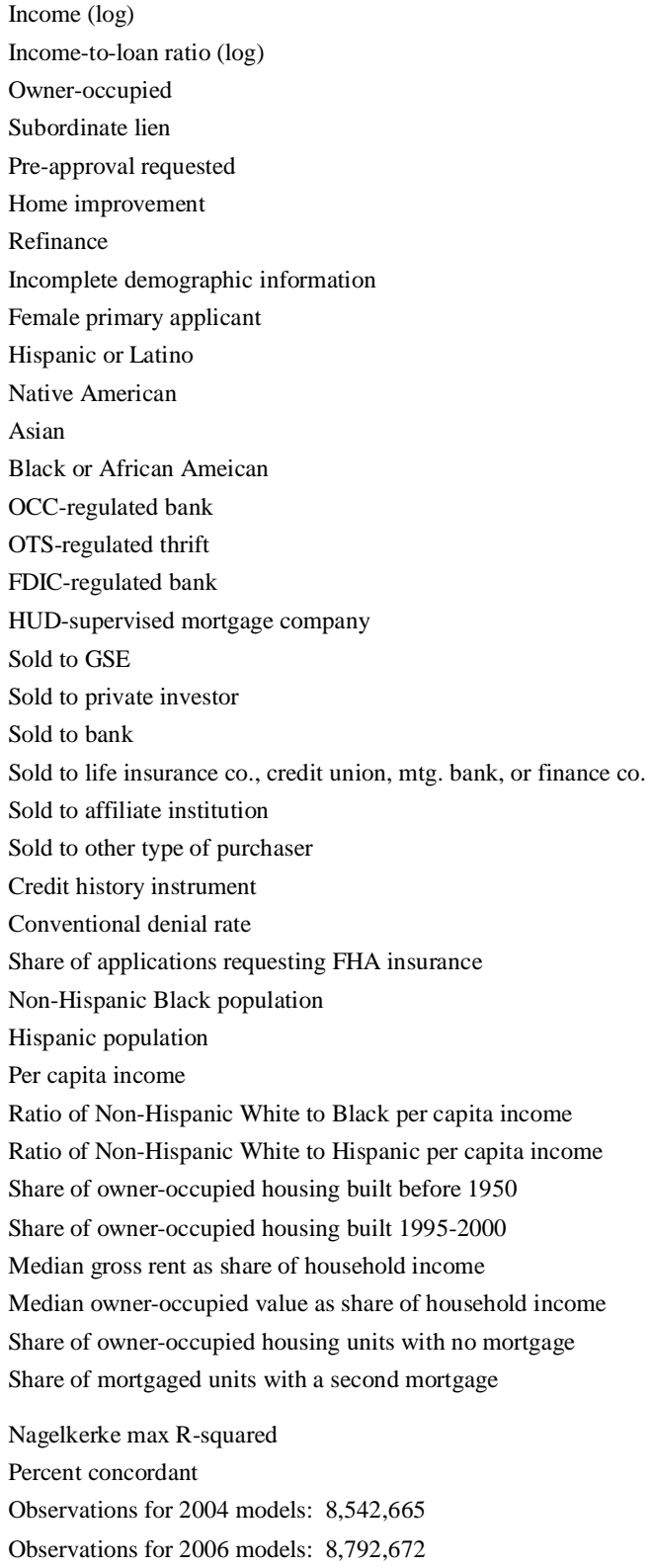

Data Source: Federal Financial Institutions Examination Council (2005, 2007).

passing on to a trust or SIV -- was more than twice as likely to be subprime. In light of what is now known about the deteriorating quality of loans made in the latter months of 2006, it is clear that the securitization system had fused a toxic brew from the most volatile compounds of 
economic chemistry (adverse selection, principal-agents dilemmas, information asymmetries) to create perverse incentives encouraging loans destined to end in foreclosure (Dymski 2007; Immergluck 2008).

The fifth finding suggests no clear role for urban and regional context. Adding a vector of theoretically relevant metropolitan measures adds almost nothing to model fit, and yields standardized odds ratios that all fall in a narrow range between 0.94 and 1.11 (Model 4). The largest effects are for metropolitan denial rates and white-black income inequality (both positive) but the effects are modest for all metropolitan indicators. After accounting for secondary investment networks, banking industry structure, and applicant characteristics, it seems that class-monopoly rent displays no contextual bias towards particular kinds of places. This finding undermines an important hypothesis.

\section{Acknowledging Geographical Contingency}

Adding "metropolitan indicators" to a model is only one way to capture the distinctions of place. Another approach is to recognize that the processes summarized in a particular model may vary across different settings. There are several intricate ways to analyze this variation (expansion techniques, multilevel models) but here we consider the obvious, simplest approach: estimating Model 3 (Table 4) separately for all metropolitan areas. This boosts model fit considerably for most places, and yields varied coefficient estimates for relations of particular concern. We focus here on the geographical contingency of racial subprime segmentation for African Americans (Figure 2) and Latinas/Latinos (Figure 3), and the nexus of subprime segmentation, applicant income, and secondary-market sales networks (Figure 4).

These graphs offer vivid portraits of the contextual landscape of capital flows. Subprime credit is deeply racialized across most but not all housing markets: most metropolitan areas appear in the top portion of the graphs in Figures 2 and 3. For African Americans, many of the larger cities post coefficients between 0.75 and 1.00 - all else constant, Blacks are between 2.1 and 2.7 times more likely than otherwise identical non-Hispanic Whites to wind up with subprime credit. For Hispanics, most of the odds ratios range from 1.65 to 2.7. Likewise, the general pattern of class segmentation and secondary-market sales conduits is clear. Most metropolitan areas in Figure 4 appear in the upper-left quadrant: all else constant, in most places subprime loans are targeted towards lower-income borrowers, and are more likely than prime loans to be sold immediately to SPVs and other purchasers. These general patterns conform well to the hypothesis that class-monopoly rents are extracted from across the urban system - but in uneven ways that inscribe distinctive local credit environments.

Nevertheless, urban and regional contingencies matter. Quite a few metropolitan areas cluster along one of the axes, indicating no statistically significant segmentation for race/ethnicity (Figures 2, 3) or class/secondary circuits (Figure 4). In several metropolitan areas, the prevailing patterns are reversed. Subprime segmentation is significantly less likely for African Americans in places like Flint, Michigan, Rochester, New York, and Pensacola, Florida; for Latinas and Latinos, these effects appear in Pueblo, Colorado, and the locally transnationalized, multigenerational Texas border cities of El Paso and Laredo. There are even more exceptional cases for income and loan-sales networks: in four dozen metropolitan areas, subprime credit is ceteris 
paribus more likely for higher-income applicants. The effects are not substantively large ${ }^{15}$ but they provide a direct counterpart to the general trend; given the controls included in the models, these effects cannot be attributed to a greater prevalence of investor-buyers, higher debt burdens, or different mix of homebuyers and applicants seeking to refinance. After accounting for these factors, part of the subprime boom appears to have involved higher-income applicants responding to the imperatives of extremely tight housing markets in big cities -- the Twin Cities, San Diego, Salt Lake City, Portland, Sacramento; but even stronger effects appear in smaller regional trade centers, and in exurban towns transformed by dramatic increases in long-distance commuter suburbs. Some of these places - San Diego, Minneapolis-St. Paul, Portland - are highlighted in Immergluck's (2008) analysis of the expansion of ARMs and zero-downpayment loans in the cumulative-causation cycle of "exotic" mortgages in the home purchase market: rising prices in overheated markets induce lenders and buyers to use more flexible instruments, which in turn enable sellers to demand still higher prices. But many other cities on our graph do not correspond neatly with Immergluck's analyses (see p. 7, 9, 13). Compared with the durable divisions of race and ethnicity, there is considerable metropolitan contingency in the class focus of subprime capital.

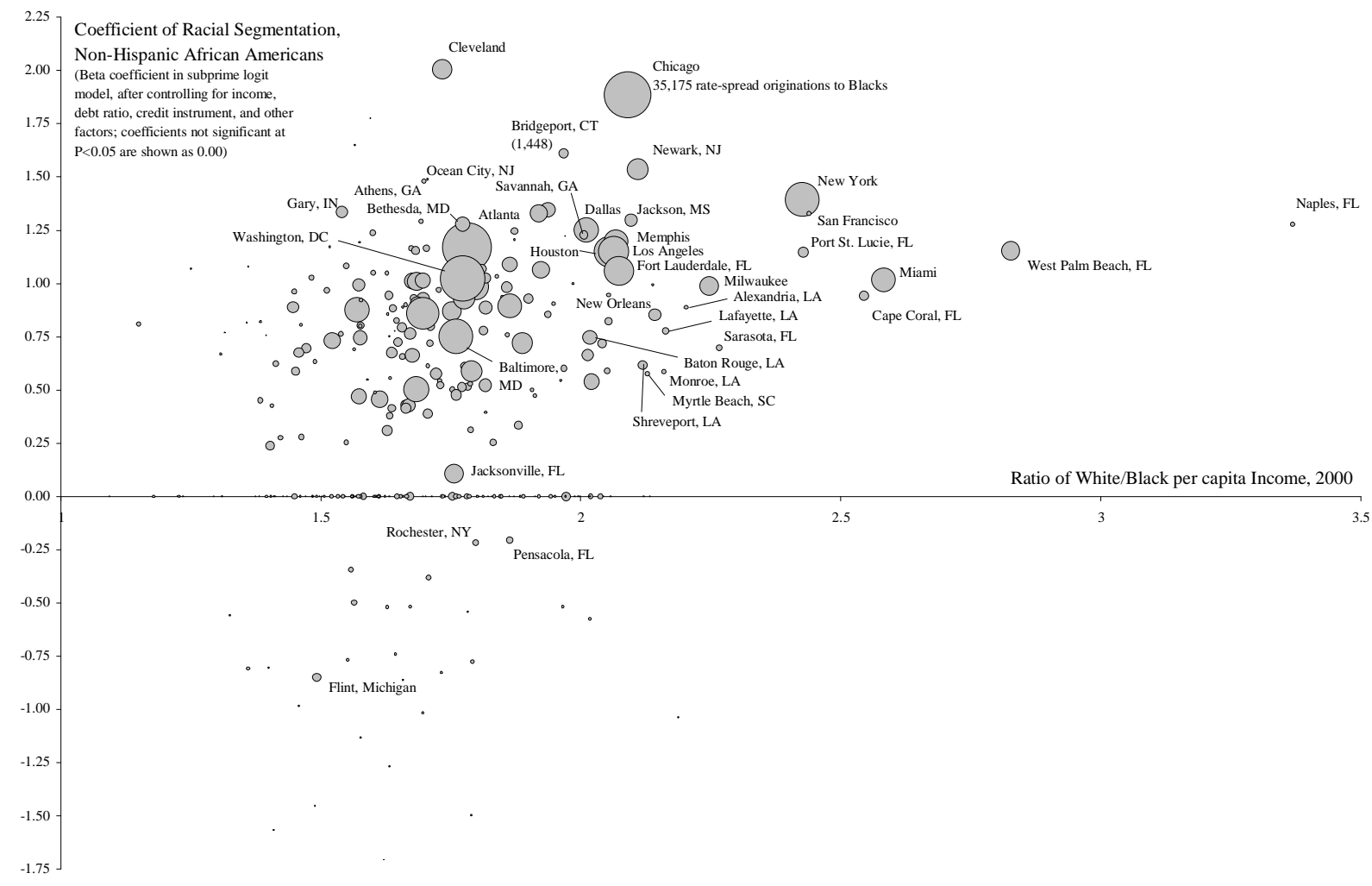

Figure 2. Metropolitan Coefficients of Racial Segmentation, Non-Hispanic African American Borrowers, 2006. Circle sizes are proportional to the number of rate-spread originations to NonHispanic Blacks. Data Sources: FFIEC (2007), U.S. Census 2000 (per capita income data).

\footnotetext{
${ }^{15}$ For metropolitan areas near Minneapolis-St. Paul on the graph, increasing applicant income from about $\$ 100,000$ to $\$ 350,000$ increases the odds of subprime selection by a ratio of about 1.07 .
} 


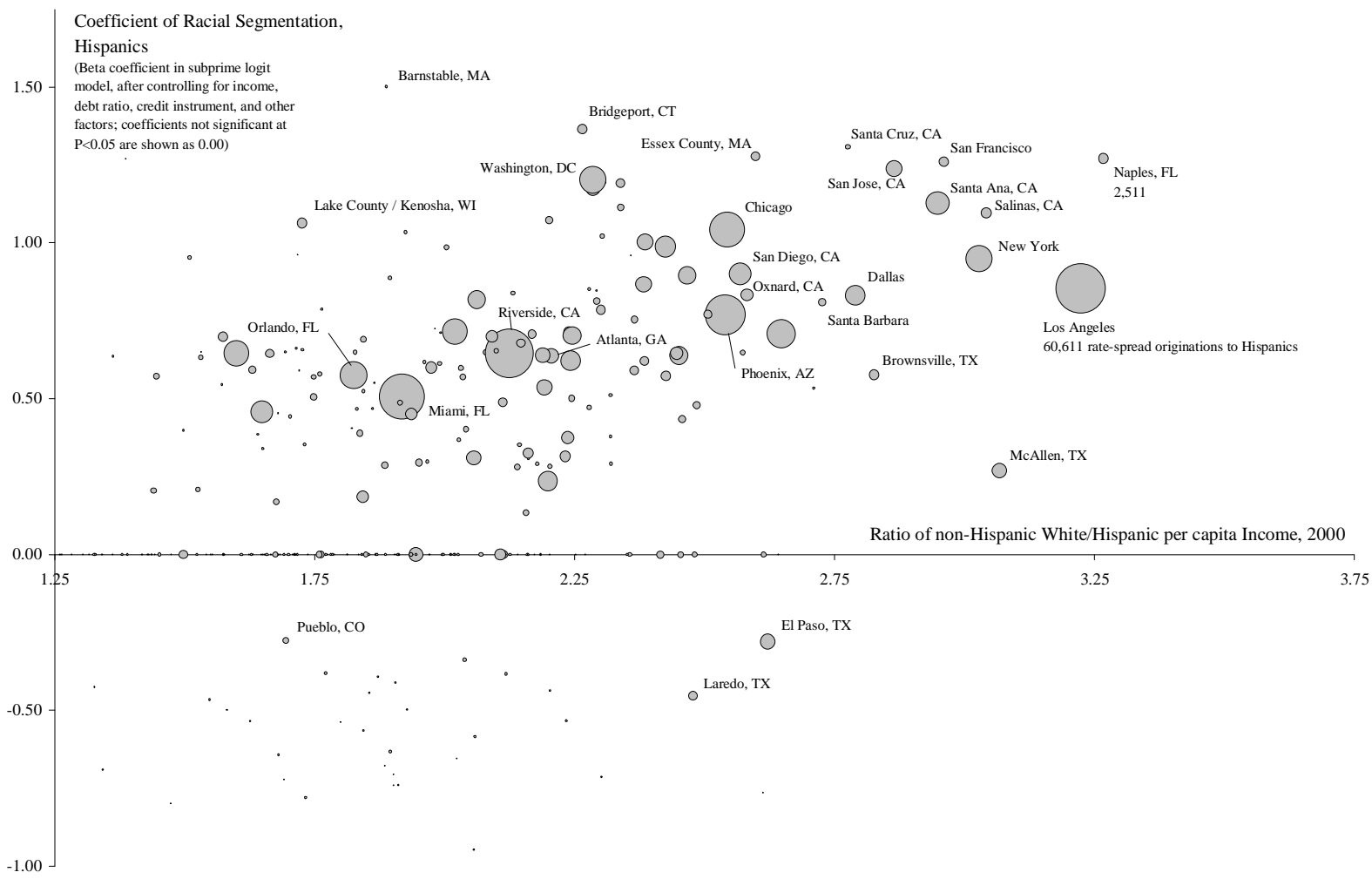

Figure 3. Metropolitan Coefficients of Racial Segmentation, Latino/Latina Borrowers, 2006. Circle sizes are proportional to the number of rate-spread originations to Hispanics. Data Sources: FFIEC (2007), U.S. Census 2000 (per capita income data). 


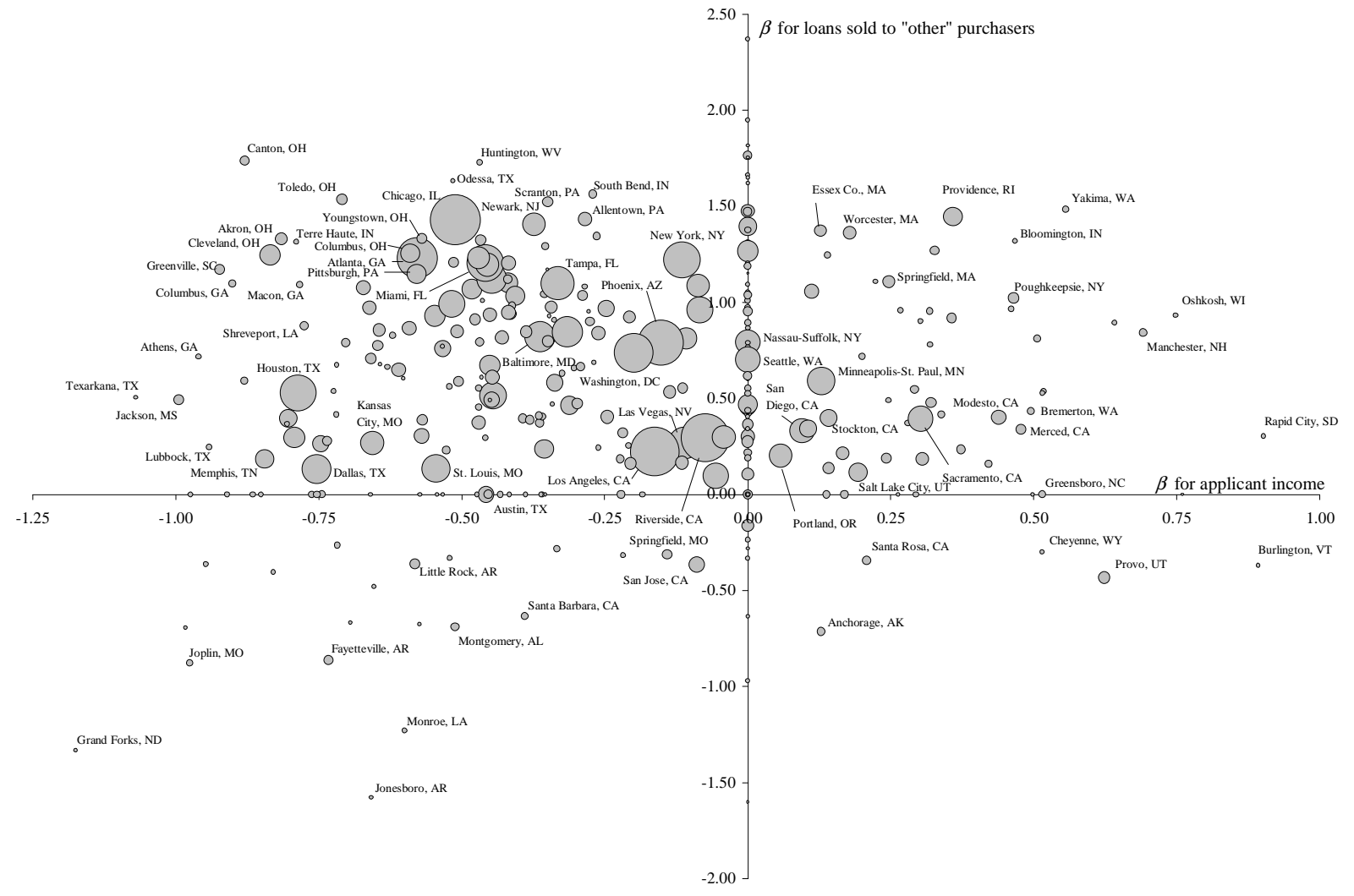

Figure 4. Metropolitan Coefficients of Income Segmentation and SPV Sales Conduits, 2006. Coefficients not significant at $\mathrm{P}<0.05$ are shown as 0.00 , thus appearing on one of the axes. Circle sizes are proportional to the number of rate-spread originations. Data Source: FFIEC (2007).

\section{Spaces of Mobilization}

Our third hypothesis deals with the relations between the material spaces of class-monopoly rent and the representational spaces of organization and action. The race and class inequalities measured in Figures 2, 3, and 4 have consequences that are serious and real: current housing market conditions suggest that subprime foreclosures will turn at least 2 million homeowners into renters over the next two years, stripping them of at least $\$ 71$ billion in housing wealth (Schumer et al. 2007: 1); African American and Latino borrowers have already lost at least \$146 billion in housing wealth from subprime loans between 1998 and 2006 (Rivera et al. 2008: vii). Yet these material realities are dynamic, multi-faceted social constructions: our graphs provide only the most partial, limited view of one dimension of the market. Behind each of the dots on these graphs are struggles between homeowners, brokers, lenders, regulators, and investors. These struggles articulate multiple ties among individuals and institutions at different geographical scales, perforating and stretching the simple Euclidian map of the nation's urban network. Progressive possibilities are apparent if we recall Peter Gould's (1986: 202) reminder: "Space is not a wastepaper basket that sits there waiting for us to fill it with things, but something we define to suit our needs." 
Three types of multi-scalar places are being constructed to challenge some of the exploitations of subprime class-monopoly rent. First, federal agencies have belatedly taken some of the steps that advocates have demanded for years. In early December, 2007, the Bush Administration launched "FHA Secure," granting the Federal Housing Administration limited authority to help (some) subprime borrowers refinance on better terms, and also convened a private consortium of lenders -- the HOPE NOW Alliance -- who informally agreed to try to provide limited relief to some borrowers in distress (Bush 2007). At the same time, the Federal Reserve proposed amendments to Regulation Z, the specific rule that implements the Truth in Lending Act (TILA) and the Home Ownership and Equity Protection Act (HOEPA) (Federal Reserve Board 2007). Some of the detailed provisions hold the potential to reduce certain abusive practices in the future. Unfortunately, the Fed's consistent refusal to take these actions for more than a decade enabled the boom, as lenders easily skirted the provisions of TILA and HOEPA; the Fed had full authority after HOEPA's passage in 1994 to take the actions announced in December, 2007, after much of the subprime industry had collapsed. Other federal responses may yield some, limited post hoc accountability: the Securities and Exchange Commission has launched three dozen investigations into how subprime loans were originated, packaged, and valued in the secondary market, the Internal Revenue Service has opened an inquiry into the special trusts used to issue MBSs, and the Federal Bureau of Investigation has begun criminal inquiries into more than a dozen subprime companies suspected of accounting fraud, insider trading, and other violations (Bajaj 2008a; Browning 2008). Many state officials have also launched investigations, although the prospects for these actions depend on the peculiar historical-legal constructions of jurisdiction and federalism. New York State occupies a distinctive position in this federalist regulatory space: Wall Street financial institutions are at the heart of the subprime capital machine and its extraction of class-monopoly rents, and the state's Martin Act gives the New York Attorney General both civil and criminal jurisdiction of a wide range of securities-related matters. The current AG, Andrew Cuomo, has begun investigations into whether Wall Street investment banks withheld materially relevant information on the quality of loans they packaged into securities (Anderson and Bajaj 2008); to use the economics language of credit rationing theory (Stiglitz and Weiss 1981), Cuomo's investigation focuses on the illegal, profitable exploitation of asymmetric information by investment banks. Unfortunately, the evolving "mixed federalism" of American law has created overlapping, incomplete, and sometimes contradictory spheres of jurisdiction by state, federal, and local officials. Most of the innovations of subprime structured finance involved attempts to exploit this situation: one of the reasons why Special Purpose Vehicles are so special, for instance, is that they were specially designed to break the chain of legal liability. Peterson (2005: 8) goes so far as to suggest that debates over federalism "are used to mask a substantively anti-consumer policy agenda" and to advance "the covert protection of a powerful industry that profits, either directly or indirectly, from predatory lending."

Second, local and municipal litigation is percolating from private parties in many of the places highlighted in various parts of Figures 2,3, and 4. The uneven legal terrain is certainly confusing, and the route to structural change is unclear. ${ }^{16}$ Yet many of the legal innovations

\footnotetext{
${ }^{16}$ As Tamar Frankel, a law professor at Boston University, puts it: "Everybody blames everybody else," and among lenders, brokers, investment banks, and bond-rating agencies, "there isn't one who doesn't blame another, and there
} 
devised by the industry to avoid facing challenges from homeowner victims of predatory abuse may not be as effective against angry investors and other institutions. Legal actions will redraw parts of the maps portrayed in Figures 2, 3, and 4: "Wall Street banks that sold mortgage investments around the world face legal complaints from as far away as Australia and Norway. Lehman Brothers, the Wall Street investment bank with the biggest mortgage business, is being sued by towns in Australia that say a division of the firm improperly sold them risky mortgagerelated investments." (Bajaj 2007: C9). In some cases, the rapid and seemingly-sophisticated practices of structured finance encouraged certain shortcuts that now expose the exploitation infrastructure of class-monopoly rent: in late October, 2007, Deutsche Bank National Trust Company was rebuffed in its attempt, acting as a trustee for securitization pools, to foreclose on 14 homeowners in Ohio. When the judge issued the routine order for the lenders' attorneys to furnish copies of the loan assignment documents proving true ownership of the loans, Deutsche's representatives could only produce paperwork showing an intent to convey the rights from one institution to another. In the accelerated pace of securitization, formal, actual conveyance of legal documents became a technical formality that many lenders, trusts, and SPVs seem to have ignored. The judge's dismissal of the foreclosure proceedings may not withstand appeal, but it is certainly possible that more of the securitization agents long accustomed to extracting classmonopoly rents may face the same kinds of fine-print sticker shock that they have inflicted on borrowers (Boyko 2007). ${ }^{17}$

Cities are also fighting back. Note the position of Cleveland on Figure 2. Cleveland Mayor Frank Jackson declared that 21 large financial institutions would be "held accountable for what they've done" in a wave of subprime lending that has left the city with more than 7,000 foreclosures in each of the last two years (Maag 2008); Jackson spoke to announce a lawsuit filed by the City under Ohio's common-law definition of a public nuisance (City of Cleveland 2008). Cleveland's suit names the most prominent Wall Street institutions: Deutsche Bank, Bank of America, Bear Stearns, Citigroup, Countrywide, Credit Suisse, Goldman Sachs, HSBC, J.P. Morgan, Lehman Brothers, Merrill Lynch, Morgan Stanley, Wells Fargo, and several others. In Baltimore, the neighborhoods devastated by one kind of racial and class exploitation decades ago (Harvey 1974: 246-247) have been stripped of wealth by the new infrastructure of classmonopoly rent (Wyly et al. 2006: 121-122); now the Mayor and City Council are fighting back with a suit against the lender with the largest number of foreclosures in the city -- Wells Fargo. In contrast to Cleveland's public-nuisance claim, Baltimore is pursuing the more potent claim of racial targeting and violation of the Fair Housing Act (see Engel 2006: 382-389; Morgenson 2008a). Baltimore is represented by John P. Relman, a civil-rights and fair-lending litigator with an impressive track record that holds considerable promise to redraw at least part of the legal landscape of predatory class-monopoly rent (see Relman 2003, 2004, Mayor and City Council of Baltimore 2008).

is half-truth in everything." (quoted in Bajaj 2008b: C9). As of December, 2007, 32 new class-action lawsuits had been filed over the subprime mortgage crisis (Bajaj 2008b: C9).

${ }^{17}$ U.S. District Judge Boyko's order is strident and spirited, a progressive incarnation of a Scalia opinion. Boyko found Deutsche's un-documented ownership claims "astounding": "Plaintiff's 'Judge, you just don't understand how things work' argument reveals a condescending mindset and quasi-monopolistic system where financial institutions have traditionally controlled, and still control, the foreclosure process." (Boyko 2007: 5). Other courts are pulling back the curtain to find evidence of questionable practices, such as Countrywide's alleged fabrication of letters that were never in fact sent to delinquent borrowers (see Morgenson 2008b). 


\section{Mapping the New State of Play}

A third route of challenge has focused on state legislatures. While reform efforts were subverted at the federal level for many years, a wave of state legislation since North Carolina's landmark 1999 law has "thrust state legislatures back into their traditional role as local laboratories for the development of new, experimental remedies and causes of action." (Relman 2004: 168). More than two dozen states have passed some kind of legislation to combat predatory home lending (Butera \& Andrews 2007). Analyses of public data as well as private, industry datasets have indicated that, overall, state laws have succeeded in reducing the prevalence of specific targeted practices without restricting overall access to credit or increasing costs to consumers ( $\mathrm{Li}$ and Ernst 2006, 2007; Quercia et al. 2004). Until recently, however, it has been nearly impossible to map the complex and shifting legal/regulatory landscape. Several recent advances now make it possible to see what has been achieved through years of organizing, research, and policy advocacy. Ambrose and Pennington-Cross (2000) developed a taxonomy of state laws on foreclosures and deficiency judgments (see also Pence 2003). ${ }^{18} \mathrm{Li}$ and Ernst $(2006,2007)$ undertook a detailed, comprehensive examination of how a 'typical' subprime loan would be regulated -- if at all -- under the many state laws that took effect between 2000 and 2005. Their analysis classifies states according to regulations on maximum permissible points, fees, and interest rates, yield-spread premiums, prepayment penalties, loan flipping, pre-loan counseling requirements, legal remedies for lender violations, and coverage of open-ended home equity loans.

We seek to map this legislative/regulative landscape, and to test whether it has achieved any significant effects on the urban and regional inequalities of class-monopoly rent. We assembled a state-level database combining the classifications of Ambrose and Pennington-Cross (2000), Li and Ernst (2006, 2007), and Pence (2003) to distill the complex patchwork of state regulatory regimes into seven ordinal, ranked measures of the degree of protection against predatory abuses beyond the minimal, federal HOEPA statute. To measure the similarities among various states, we calculated the inverse of Gower's (1971) similarity coefficient, a metric designed to correlate nominal or ordinal variables so that numerical operations requiring a positive semi-definite correlation matrix can be used in subsequent steps. A standard multidimensional scaling procedure (Kruskal and Wish 1978) then deploys a series of matrix-algebra operations to create a two-dimensional representation of the distances separating the states in the seven-dimensional space of mortgage market regulation. ${ }^{19}$

\footnotetext{
${ }^{18}$ Borrowers who fall behind on their payments receive the most protection in states where foreclosures must go through a judicial process, and where lenders cannot receive deficiency judgments that take a debtor's non-housing assets to satisfy foreclosure losses. In creditor-friendly states, lenders can pursue expedited non-judicial foreclosures and receive deficiency judgments.

${ }^{19}$ As with any map projection, this operation involves some distortion; but our analysis yields a robust badness-offit criterion of only 0.117 , and an encouragingly tight correlation (0.98) between the mathematically calculated and mapped distances among all possible 1,275 state-pairs.
} 

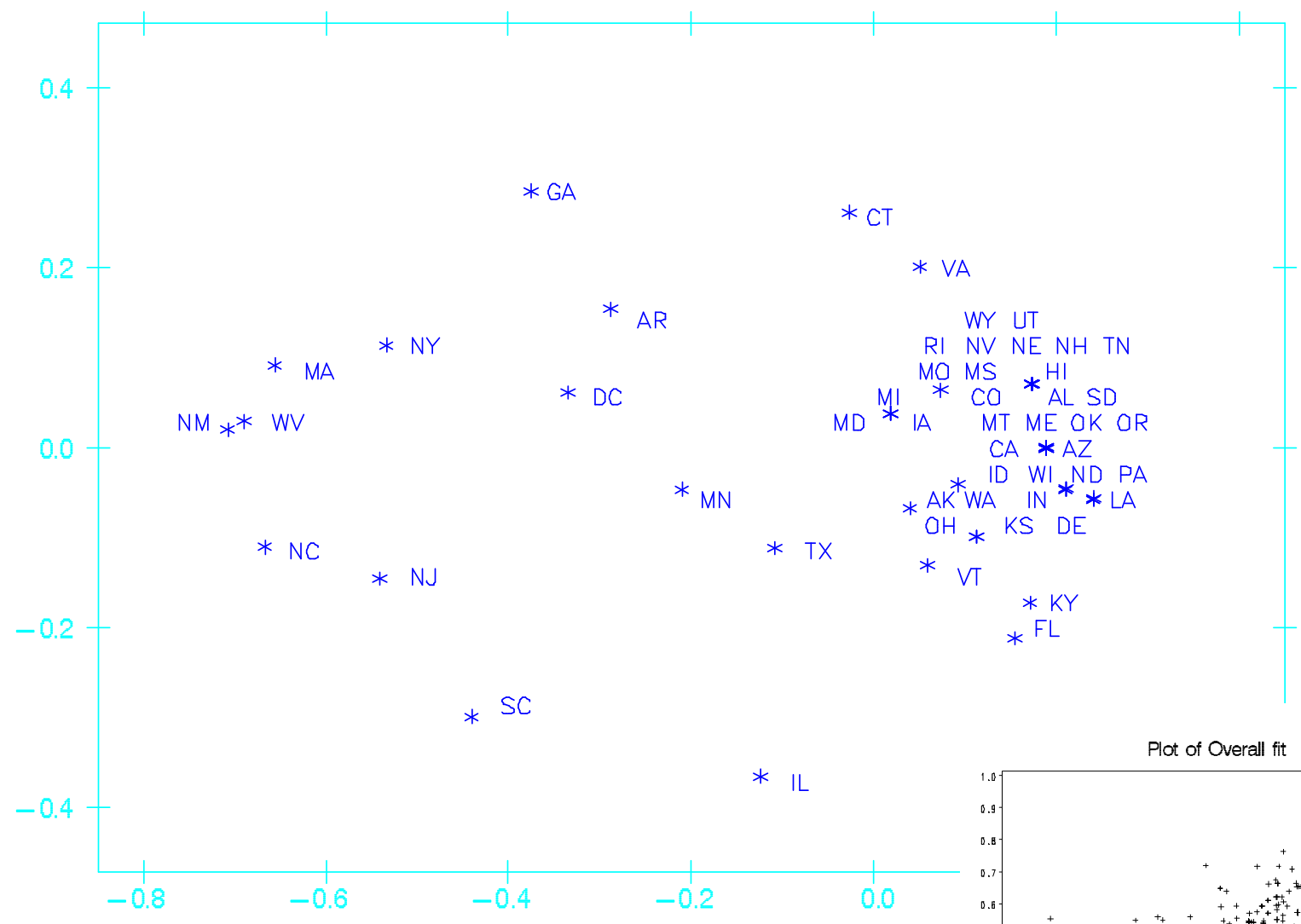

Figure 5. The Legal Space of State Anti-Predatory Lending Laws and Foreclosure Regulations, 2004.

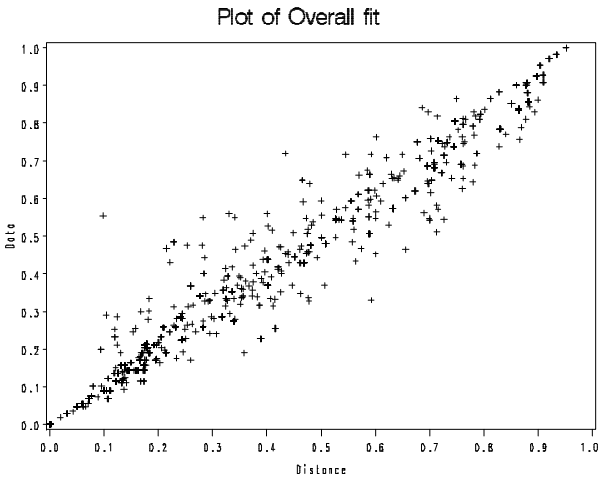

States with similar regulatory regimes are shown close together on the "map" represented in the panel above; borrower protections are greater on the west side (left) of this map. This map is, however, a two-dimensional representation derived from a matrix of similarities between states measured on several regulatory variables (loan flipping, prepayment penalties, points and fees, foreclosure rules, etc.). Simplifying this matrix in two dimensions does introduce some error or 'stress' in the fabric of the map. The panel at right shows residuals between the raw data and the distances between pairs of states as shown in the map above; all points would cluster on the diagonal if the model fit the data perfectly. In our analysis, the largest residuals separate Virginia (from Connecticut and Georgia) and Connecticut (from not only Virginia, but also Arkansas, Michigan, Maryland, and Iowa). Data Sources: Li and Ernst (2006), Ambrose and Pennington-Cross (2000), Pence (2003).

The result is a simple map (Figure 5). This representation is different from the previous charts: it does not plot observations according to values along horizontal and vertical axes; it is instead a map of the distances separating different states in the evolving legislative spaces created by organizers, policy analysts, state lawmakers, and banking-industry lobbyists. In the east northcentral portion of the map, as of 2004, eleven states had absolutely no protections beyond the 
weak federal HOEPA rules: Alabama, Mississippi, Colorado, Nebraska, Wyoming, Utah, Tennessee, New Hampshire, Rhode Island, and Hawaii. These states also allow lenders to use expedited non-judicial foreclosures with deficiency judgments. Moving away from this laissezfair point on the map, borrowers are granted greater legal protections against abuses of subprime class-monopoly rent. Legislative tradeoffs, priorities, and compromises create distinct regulatory regimes: to the 'south' on Figure 5, Illinois regulates loan flipping -- requiring lenders to consider the tangible net benefit of certain types of refinance loans that otherwise fall below high-cost triggers -- and also requires counseling for certain high-cost loans. By contrast, to the 'north,' Georgia's regulations focus on limiting points, fees, and prepayment penalties. The central area of the map includes states with strong protections against flipping, but with moderate or weak provisions for other terms. Finally, a group of states on the 'western' fringe -- North Carolina, Massachusetts, West Virginia, and New Mexico -- passed legislation that regulates a wide range of practices. New Mexico stands out as the gold standard as of 2004, thanks to SB 0449, the Home Loan Protection Act, passed in April, 2003. The regulations cap points and fees to two percent of the loan amount, prohibit loan flipping "when the new loan does not have reasonable, tangible net benefit to the borrower considering all of the circumstances," restricts balloon provisions, bans negative amortization, asset-based lending, prepayment penalties, credit life insurance sales, and penalty interest rates. The law also mandates counseling for high-cost loans, and permits limited assignee liability -- so that institutional investors buying loans from front-line lenders will share responsibility if crimes were committed in the transaction used to consummate the loan with the borrower. The structured finance industry has fought assignee liability with ferocious power (Engel and McCoy 2007); industry advocates rightly understand this legal provision as a direct threat to their rights to extract class-monopoly rents from blatantly illegal, deceptive, and discriminatory transactions.

Has this evolving legislative landscape altered the experiences of homeowners and homebuyers? Has it had any effect on the circuits of class-monopoly rent diagnosed earlier? To answer these questions, we re-estimated the loan-level models presented in Table 4 (Model 4); for the state in which each applicant's collateral property is located, we added a measure of how far the state is from New Mexico in the space of lending regulation as shown in Figure 5 (we used deciles to allow for non-linearity). The model results indicate significant effects on subprime segmentation, even after accounting for the income and estimated credit risk of applicants, the type of lender, secondary sales conduits, and even the demographic and economic circumstances of metropolitan housing markets. All else constant, going from New Mexico towards New York or New Jersey on Figure 5 boosts the odds ratios of subprime segmentation by a factor of more than 1.3 in 2004, and more than 1.5 two years later. The effect is not linear, but nearly all deciles of distance post significant and positive coefficients in 2004, and every one does in 2006. Put simply, the decade-long struggle to fight predatory lending through state legislation does appear to have achieved significant, material changes in the extraction of class-monopoly rent. 


\section{Conclusions}

"A decade after a credit crisis in Southeast Asia triggered an 'Asian contagion' of stock market declines around the world, the credit crisis in the United States is now producing an 'American contagion' to which no stock market seems immune.” (Bajaj 2008c).

"When banks generate loans -- and hence risks -- but do not absorb risks, then their fundamental structural position in the economy is transformed .... strategic re-orientation of banks ... transformed the landscape of racial and social exclusion in U.S. credit markets: what was a scenario of financial exclusion and loan denial became a scenario of financial exploitation and loan-making. Households previously denied mortgage credit were now awarded high-cost, high-risk loans." (Dymski 2007: 1-2).

“...Wall Street securitized the sub-prime boom that took place in Cleveland and across the country.... Investment bankers bought sub-prime mortgages for use in collateral in the sale of mortgage-backed securities. This form of investment became the darling of Wall Street, given the substantial returns that purchasers were supposed to receive (in keeping with the substantial interest that sub-prime borrowers were supposed to pay on the mortgages that backed the securities).... 'Securitizers' typically paid themselves astronomical fees in putting together offerings of mortgage-backed securities. Their appetite for mortgage-backed securities became so voracious that 'securitizers' explicitly countenanced loans made to borrowers either on financially irrational terms or without any information to corroborate the borrowers' wherewithal to pay -- anything to keep the new mortgages coming for the creation of still more mortgage-backed securities." (City of Cleveland 2008: 6-7).

As America's subprime lending boom reached its crescendo and then began its descent between 2004 and 2006, the share of African Americans pushed into high-cost loans shot up from 37 percent to 54 percent, and the share for Latinas and Latinos jumped from 25 to 46 percent. In this paper, we challenged the dominant, risk-based pricing explanation for these kinds of disparities. Even after accounting for a wide range of demand-side factors, African Americans and Latinas/Latinos approved for credit were still twice as likely as otherwise identical nonHispanic Whites to wind up with high-cost loans in 2006. Inequalities are even more severe for African Americans in cities like Cleveland, Chicago, Newark, and New York; for Latinos, in smaller cities in Massachusetts, Bridgeport, Connecticut, Washington, DC, Chicago, and the San Francisco Bay Area. The analysis demonstrates that the geography of the subprime lending boom was not simply a random deviation from mainstream market outcomes: rather, the pattern was inscribed through the mutual interplay between a) the distinctive regional histories of race and uneven development across the American urban system, and b) the competitive reorientation of brokers and lenders working to find the most profitable outlets for transnational capital circuits developed by the Wall Street asset securitization industry. The framework of risk-based pricing certainly can be refined and adapted to help disentangle the information asymmetries among lenders, investors, investment banks, and bond-ratings agencies (cf. Greenwald and 
Stiglitz 1991). But the theory of risk-based pricing has become doctrine and ideology, used for well over a decade to blame consumers for the consequences of an abusive industry, to justify a de-regulatory stance that encourages usury as "innovation," and to sustain the mirage of an American Dream backed by high-risk, predatory credit. Harvey's (1974) analysis of classmonopoly rent provides a compelling theoretical and strategic alternative that emphasizes the social relations of the rights of property, ownership, and profit -- against the use values of home, community, and security. Subprime lending and Wall Street securitization have replaced the abusive local loan sharks and slum landlords with entrepreneurial brokers and lenders pushing high-cost credit backed by mortgage companies, subsidiaries of large national banks, and the entire array of investment bankers, bond traders, ratings analysts, and yield-hungry investors. The entire system is built on the extraction of class-monopoly rents: borrowers forced to pay usurious, non-competitive rates, or to surrender home equity, to individuals and institutions with specialized information and access to the means of production of mortgage obligations and financing. The specific tactics used to accumulate rents involve a wide range of seemingly obscure, technical terms -- yield-spread premiums, penalty interest rates, balloon payments, negative amortization, prepayment penalties, etc. -- but their essence is simple. Those who earn incomes by serving the circulation of mortgage capital receive far greater rights than the contingent, limited protections available to home 'owners.' Nevertheless, analysis of the evolving legal landscape -- strategic litigation, prudent regulation, proactive state legislation -demonstrates that it is possible to fight abuses and to reduce at least some of the exploitation of working-class and racially marginalized communities in the United States. 


\section{References}

Abariotes, A., S. Ahuja, H. Feldman, C. Johnson, L. Subaiya, N. Tiller, J. Urban, and S.L. Myers, Jr. (1993) Disparities in Mortgage Lending in the Upper Midwest. Paper presented at the Fannie Mae University Colloquium on Race, Poverty, and Housing Policy. Minneapolis, MN, December 3.

Ambrose, B.W., and A. Pennington-Cross (2000) Local Economic Risk Factors and the Primary and Secondary Mortgage Markets. Regional Science and Urban Economics 30, 683-701.

Anderson, J., and V. Bajaj (2008) Reviewer of Subprime Loans to Aid Inquiry. New York Times, 27 January.

Anderson, J., and V. Bajaj (2007) Calm Returns to Market, But Worries Persist Over Subprime Loans. New York Times, 1 March, C1, C4.

Andrews, E. (2007a) Bernanke Not Worried About Market Drops. New York Times, 1 March, C5.

Andrews, E. (2007b) Ex-Fed Chief Gone, But Not Forgotten. New York Times, 2 March, C1, C7.

Andrews, E. (2007c) Fed and Regulators Shrugged as the Subprime Crisis Spread. New York Times, 18 December, A1.

Ashton, P. (2008) Advantage or Disadvantage? The Changing Institutional Landscape of Underserved Mortgage Markets. Urban Affairs Review 43(3), 352-402.

Bajaj, V. (2008) FBI Looks at 14 Firms Involved in Lending. New York Times, 30 January, C1, $\mathrm{C} 2$.

Bajaj, V. (2008b) If Everyone's Finger-Pointing, Who's to Blame? New York Times, 22 January, C1, C9.

Bajaj, V. (2008c) Market's Wild Ride Ends with Dow at 15-Month Low. New York Times, 22 January, A1.

Bajaj, V., and G. Morgenson (2007) Banks Study Bailing Out Bond Insurer. New York Times, 19 December, C1, C4.

Berkovec, J.A., G.B. Canner, S.A. Gabriel, and T.H. Hanman (1994) Race, Redlining, and Mortgage Loan Performance. Journal of Real Estate Finance and Economics 9(3), 263-294.

Bernanke, B.S. (2007) The Recent Turmoil and its Economic and Policy Consequences. 15 October, remarks at New York Economic Club. Washington, DC: Board of Governors of the Federal Reserve. 
Berry, B.J.L. (1964) Cities as Systems Within Systems of Cities. Papers of the Regional Science Association 13, 147-163.

Birchall, J. (2007) Default Position: The Cost of America's Subprime Crisis is Clear in Youngstown, Ohio. Financial Times Weekend Magazine, 22 September, 25.

Bloomberg Markets (2008) Back of the Envelope: \$146 Billion and Counting. New York Times, 1 February, C6.

Boyko, C.A. (2007) Opinion and Order In Re Foreclosure Cases 1:07CV2282 et al. 31 October. Cleveland, OH: U.S. District Court, Northern District of Ohio, Eastern Division.

Braunstein, S. F. (2007) Statement of Sandra F. Braunstein, Federal Reserve Division of Consumer Affairs. Congressional Testimony, 25 July. Washington, DC: States News Service / Federal Reserve Board.

Brenoff, A. (2007) Stuck in a Glut. Los Angeles Times, 14 October, K1.

Brooks, D. (2008) Two Cheers for Wall Street. New York Times Op-Ed, 25 January, A27.

Brooks, R., and C.M. Ford (2007) The United States of Subprime: Data Show Bad Loans Permeate the Nation. Wall Street Journal, 11 October, A1.

Browning, L. (2008) Small Law Firm at Center of Loan Universe. New York Times, 1 February, C6.

Bush, G.W. (2008) President Bush Discusses Housing. Roosevelt Room, 6 December. Washington, DC: White House, Office of the Press Secretary.

Butera \& Andrews (2007) State and Local Predatory Lending Laws, as of January 22, 2007. Washington, DC: Butera \& Andrews, Attorneys at Law.

Carr, J.H., and L. Kolluri (2001) Predatory Lending: An Overview. Washington, DC: Fannie Mae Foundation.

Cha, A.E. (2007) China: U.S. Mortgage Crisis a Global Problem. Washington Post, 12 December.

China Daily News (2007) California Town at 'Ground Zero.' Agence France-Presse, 19 September 19.

City of Cleveland (2008) City of Cleveland vs. Deutsche Bank et al. CV 08 646970. Cleveland: Cuyahoga County Court of Common Pleas.

Chomsisengphet, S., and A. Pennington-Cross (2006) The Evolution of the Subprime Mortgage Market. Federal Reserve Bank of St. Louis Review 88, 31-56. 
Cutts, A.C., and R.A. Van Order (2005) On the Economics of Subprime Lending. Journal of Real Estate Finance and Economics 30(2), 167-196.

Dinham, H. (2007) Prepared Testimony of Harry Dinham on 'Preserving the American Dream: Predatory Lending Practices and Home Foreclosures. Washington, DC: Committee on Banking, Housing, and Urban Affairs, U.S. Senate. 7 February.

Dougherty, C. (2007a) \$300 Billion in Write-Offs is Predicted. New York Times, 23 November, C3.

Dougherty, C. (2007b) Europe Puts $\$ 500$ Billion into Banks to Ease Credit. New York Times, 19 December, C5.

Dymski, G.A. (2007) From Financial Exploitation to Global Banking Instability: Two Overlooked Roots of the Subprime Crisis. Sacramento, CA: University of California Center Sacramento, 11 December.

Eckholm, E. (2007) Foreclosures Force Suburbs to Fight Back. New York Times, 23 March, A1.

Engel, K.C. (2006) Do Cities Have Standing? Redressing the Externalities of Predatory Lending. Connecticut Law Review 38(3), 355-391.

Engel, K.C., and P.A. McCoy (2007) Turning a Blind Eye: Wall Street Finance of Predatory Lending. Fordham Law Review 75(4), 2039-2103.

Engel, K.C., and P.A. McCoy (2002) A Tale of Three Markets: The Law and Economics of Predatory Lending. Texas Law Review 80(6), 1255-1381.

Evans, A.W. (1991) On Monopoly Rent. Land Economics 67(1), 1-14.

Fabozzi, F., ed. (2001) Handbook of Mortgage-Backed Securities, Fifth Edition. New York: McGraw-Hill.

Federal Deposit Insurance Corporation (2005) Frequently Asked Questions about the New HMDA Data. Washington, DC: FDIC.

Federal Financial Institutions Examination Council (Annual) HMDA Raw Data Loan Application Register Data on CD-ROM. Washington, DC: Board of Governors of the Federal Reserve.

Federal Reserve Board (2007) Proposed Rule, Revisions to Regulation Z. Draft Federal Register Notice and Request for Comment. December 18. Washington, DC: Board of Governors of the Federal Reserve.

Ferguson, N. (2007) Living on Borrowed Time. Los Angeles Times, 16 July, A15. 
Financial Post (2007) Miami Condominium Appears to be at Ground Zero in Blizzard of Fraud. Reuters. Financial Post, 14 November, 5.

Friedman, T.L. (2007) The World is Flat. New York: Picador.

Gotham, K.F. (2006) The Secondary Circuit of Capital Reconsidered: Globalization and the U.S. Real Estate Sector. American Journal of Sociology 112(1), 231-275.

Gould, P.R. (1986) The Geographer at Work. London: Routledge.

Gower, J.C. (1971) A General Coefficient of Similarity and Some of its Properties. Biometrics 27(4), 857-871.

Greenspan, A. (2007) U.S. Moving Closer to Recession. Appearance on ABC News This Week. December 16, available at http://www.abcnews.com.

Greenwald, B., and J.E. Stiglitz (2005) Information, Finance, and Markets. In G. Dosi, D.J. Teece, and J. Chytry, eds., Understanding Industrial and Corporate Change. Oxford: Oxford University Press, 167-192.

Greenwald, B., and J.E. Stiglitz (1991) Information, Finance, and Markets: The Architecture of Allocative Mechanisms. Working Paper 3652. Cambridge, MA: National Bureau of Economic Research.

Gross, D. (2007) The New Money Pit. Newsweek, 10 September, 28.

Harvey, D. (1985) The Urbanization of Capital. Baltimore: Johns Hopkins.

Harvey, D. (1981) The Limits to Capital. Chicago: University of Chicago Press.

Harvey, D. (1974) Class-Monopoly Rent, Finance Capital and the Urban Revolution. Regional Studies 8, 239-255.

Henderson, N. (2007) Market Maelstrom: After Two-Day Nosedive, The Talk Ranged From Long-Term to Downturn. Washington Post, 29 July, F1.

Holloway, S.R. (1998) Exploring the Neighborhood Contingency of Race Discrimination in Mortgage Lending in Columbus, Ohio. Annals of the Association of American Geographers 88(2), 252-276.

HUD-Treasury Joint Task Force (2000) Final Report of the Joint Task Force on Predatory Lending. Washington, DC: U.S. Department of Housing and Urban Development.

Immergluck, D. (2008) From the Subprime to the Exotic: Excessive Mortgage Market Risk and Foreclosures. Journal of the American Planning Association 74(1), 1-18. 
Krueckeberg, D. (1999) The Grapes of Rent: A History of Renting in a Country of Owners. Housing Policy Debate 10(1), 9-30.

Kruskal, J.B, and M. Wish (1978) Multidimensional Scaling. QASS 07-011. Thousand Oaks, CA: Sage Publications.

Landler, M. (2007) US Credit Crisis Add to Gloom in Norway. New York Times, 2 December, A1.

Lax, H., M. Manti, P. Raca, and P. Zorn (2004) Subprime Lending: An Investigation of Economic Efficiency. Housing Policy Debate 15(3), 533-571.

Li, Wei, and K. Ernst (2007) Do State Predatory Lending Laws Work? A Panel Analysis of Market Reforms. Housing Policy Debate 18(2), 347-391.

Li, Wei, and K. Ernst (2006) The Best Value in the Subprime Market: State Predatory Lending Reforms. Durham, NC: Center for Responsible Lending.

Listokin, D., et al. (2000) Making New Mortgage Markets. Washington, DC: Fannie Mae Foundation.

Litan, R.E. (2001) A Prudent Approach to Preventing 'Predatory' Lending. Washington, DC: Brookings.

Maag, C. (2008) Cleveland Sues 21 Lenders Over Subprime Mortgages. New York Times, 12 January.

Mansfield, C.L. (2000) The Road to Subprime HEL Was Paved With Good Congressional Intentions: Usury Deregulation and the Subprime Home Equity Market. South Carolina Law Review 51.3, 473-594.

Mayor and City Council of Baltimore (2008) Mayor and City Council of Baltimore v. Wells Fargo Bank, N.A., and Wells Fargo Financial Leasing, Inc. L08 CV062. Baltimore: U.S. District Court for the District of Maryland, Baltimore Division.

Miller, M.J., ed. (2003) Credit Reporting Systems and the International Economy. Cambridge, MA: MIT Press.

Morgenson, G. (2008a) Baltimore is Suing Bank Over Foreclosure Crisis. New York Times, 8 January, A12.

Morgenson, G. (2008b) Lenders Tells Judge it 'Recreated' Letters. New York Times, 8 January, C3.

Myers, S.L., Jr., and T. Chan (1995) Racial Discrimination in Credit Markets: Accounting for Credit Risk. Social Science Quarterly 76, 543-561. 
Myrdal, G. (1944) An American Dilemma. New York: Harper \& Row.

Norris, F. (2007) A Worrisome New Wrinkle in Bailouts. New York Times, 14 December, C1, C13.

Pearlstein, S. (2007) No Money Down Falls Flat. Washington Post, 14 March, D1.

Pence, K.M. (2003) Foreclosing on Opportunity: State Laws and Mortgage Credit. Washington, DC: Board of Governors of the Federal Reserve.

Peterson, C. (2007) Predatory Structured Finance. Gainesville: Levin College of Law, University of Florida.

Peterson, C. (2005) Federalism and Predatory Lending: Unmasking the Deregulatory Agenda. Temple Law Review 78(1), 1-98.

Quercia, R.G., M.A. Stegman, and W.R. Davis (2004) Assessing the Impact of North Carolina's Predatory Lending Law. Housing Policy Debate 15(3), 573-601.

Relman, J.P. (2003) Taking it to the Courts: Litigation and the Reform of Financial Institutions. In G.D. Squires, ed., Organizing Access to Capital. Philadelphia: Temple University Press, 5571.

Relman, J.P., F. Rivera, M. Trehan, and S.S. Satoskar (2004) Designing Federal Legislation That Works: Legal Remedies for Predatory Lending. In G.D. Squires, ed., Why the Poor Pay More. Westport, CT: Praeger, 153-184.

Renuart, E. (2004) An Overview of the Predatory Lending Process. Housing Policy Debate 15(3), 467-502.

Retsinas, N.P., and E. S. Belsky (2002) Low-Income Homeownership: Examining the Unexamined Goal. Washington, DC/Cambridge, MA: Brookings/Harvard Joint Center for Housing Studies.

Rivera, A., B. Cotto-Escalera, A. Desai, J. Huezo, and D. Muhammad (2008) Foreclosed: State of the Dream 2008. Boston: United for a Fair Economy.

Sack, K. (2008) Voters Showing a Darker Mood than in '00 Race. New York Times, 24 January, A1, A16.

Saunders, A., and L. Allen (2002) Credit Risk Measurement: New Approaches to Value at Risk and Other Paradigms. Hoboken, NJ: Wiley.

Schumer, C.E., et al. (2007) The Subprime Lending Crisis. October. Washington, DC: Joint Economic Committee, U.S. Senate. 
Sorkin, A.R. (2002) HSBC to Buy a U.S. Lender for \$14.2 Billion. New York Times, 15 November, C1, C10.

Squires, G.D., ed. (1992) From Redlining to Reinvestment. Philadelphia: Temple University Press.

Squires, G.D., ed. (2003) Organizing Access to Capital. Philadelphia: Temple University Press.

Squires, G.D., ed. (2004) Why the Poor Pay More: How to Stop Predatory Lending. Westport, CT: Praeger.

Stein, E. (2001) Quantifying the Economic Cost of Predatory Lending. Durham, NC: Center for Responsible Lending.

Stiglitz, J. E. (2007) The Economic Consequences of Mr. Bush. Vanity Fair, December.

Stiglitz, J.E., and A. Weiss (1992) Asymmetric Information in Credit Markets and its Implications for Macro-Economics. Oxford Economic Papers 44, 694-724.

Stiglitz, J.E., and A. Weiss (1981) Credit Rationing in Markets with Imperfect Information. American Economic Review 71(3), 393-410.

Vandell, K.D. (1984) Imperfect Information, Uncertainty, and Credit Rationing: Comment and Extension. Quarterly Journal of Economics 99(4), 841-863.

Weisman, S.R. (2007) Tables Turned: Poor Countries Wag Fingers at Rich Ones. New York Times, 22 October.

White, A. M. (2004) Risk-Based Mortgage Pricing: Present and Future Research. Housing Policy Debate 15(3), 503-531.

White, L.J. (2002) The Credit Reporting Industry: An Industrial Organization Analysis. In R.M. Levitch, C. Majnoni, and C. Reinhart, eds. Ratings, Ratings Agencies and the Global Financial System. Boston: Kluwer.

Whitehouse, M. (2007) Day of Reckoning: 'Subprime' Aftermath: Losing the Family Home. Wall Street Journal, 30 May.

Williams, R., R. Nesiba, and E.D. McConnel (2005) The Changing Face of Inequality in Home Mortgage Lending. Social Problems 52(2), 181-208.

Wyly, E.K., M. Atia, H. Foxcroft, D.J. Hammel, and K. Phillips-Watts (2006) American Home: Predatory Mortgage Capital and Neighborhood Spaces of Race and Class Exploitation in the United States. Geografiska Annaler 88B(1), 105-132. 